\title{
Are Family Firms Better Performers during Financial Crisis?
}

\author{
Haoyong Zhou ${ }^{*}$
}

December 1, 2011

\begin{abstract}
Despite extensive researches on efficiency of family firms in normal or good economic times, we know rather little about whether family firms are superior performers in recession times. Using a dataset covering firms from S\&P 500 (US), FTE100 (UK), DAX 30 (Germany), CAC 40 (France) and FTSE MIB 40 (Italy) during the period 2006-2010, I give empirical evidences examining the performance of family firms vis-à-vis non-family firms during the current financial crisis. I find that broadly defined family firms, comprising 35 percent of the sample, do not outperform non-family firms during the crisis whether I use market performance measure (Tobin's Q) or accounting performance measure (Operating Return on Assets (OROA)). However, family firms with founder presence (as CEO, a board member or a significant blockholder) outperform by 18 percent relative to non-family firms in OROA. Tobin's Q of founder firms, by contrast, does not exhibit difference significantly. I interpret the attenuation of founder firms' market value premium as the result of high volatility of stock prices and investors' overreaction during the crisis (Veronesi, 1999; Glode et al., 2010). Further testing shows that in the crisis, compared with non-family firms, founder firms have less administrative costs incurred. Moreover, they invest significantly less and have better access to credit market. All these findings contribute to superior accounting performance of founder firms during the crisis. My results suggest that in the financial crisis, founder firms bear the least agency cost and Tobin's Q is not a good measure of corporate performance.
\end{abstract}

JEL classifications: G30; G34; G38

Key words: family firms, performance, founder, corporate governance, financial crisis

I am grateful to Yanbo Wang for data collecting assistance. I would like to thank Prof. Morten Bennedsen, Prof. Steen Thomsen and Dr. Tat-kei Lai for their comments and suggestions. All errors are my own.

*PhD candidate, Department of Economics, Copenhagen Business School. Address: Porcelænshaven 16 A, 2000 Frederiksberg, Denmark. E-mail: hz.eco@cbs.dk 


\section{Introduction}

That family firms constitute a large proportion of national economies around the world is undeniable ( for instance, La Porta et al. for overall outlook, 1999; Anderson and Reeb in the US, 2003; Klein in Germany, 2000; Morck and Yeung in Sweden, 2003; Bennedsen et al. in Denmark, 2007; Claessens et al. in Eastern Asia, 2000). The prevalence of family firms gives rise to the question whether family firms are a more efficient organizational form. Earlier empirical studies have contradicted findings. In US public firms, for example, while Holderness and Sheehan (1988) find that family firms have a lower Tobin’s Q than non-family firms, Anderson and Reeb (2003) report the opposite findings. Empirical evidences in other countries are mixed and inconclusive (McConaughy et. al., 1998; Morck et al., 2000; Claessens et al., 2002; Cronqvist and Nilsson, 2003).

More recent researches tend to render a conclusion that family firms' outperformance is sensitive to the definitions of family firms (for instance, Maury, 2006; Miller et al., 2007) and the founders of family firms play a central role in differentiating family firms from their counterparts in corporate performance. Active involvement of founders in top management (CEO) and monitoring as directors in boards is associated with superior corporate performance (Villalonga and Amit, 2006; Miller et al., 2007).

Almost all existent literatures, however, only focus on the corporate performance comparison between family firms and non-family firms in normal economic times or good market conditions. Studies are rather scant about what the performance comparison will be during depression or recession ages. Performance examination between family and non-family firms in difficult economic times matters because it offers a comprehensive picture of firm performance in distinct 
economic backgrounds. In bad days, demand cuts from customers and credit constraints (especially for those firms which largely rely on debt financing) from financial institutions may amplify intrinsic organizational fragility, which will be reflected in corporate performance. Therefore, a superior organization, despite its performance premium during good days, is more likely to build a sturdier and stabler profile relative to an inferior organization in bad days.

The current financial crisis since 2008 gives us an experimental opportunity of making such a study empirically. Using a detailed dataset from proxy filings of firms from S\&P 500 (US), FTE100 (UK), DAX 30 (Germany), CAC 40 (France) and FTSE MIB 40 (Italy) during the period 2006-2010, I aim to contribute to the literature by conducting a performance comparison between family firms and non-family firms from Western industrialized economies during the crisis.

In this paper, I pose two research questions. The primary concern is to explore whether family firms outperform non-family firms during the current financial crisis. I find that broadly defined family firms, comprising 35 percent of the sample firms, do not significantly outperform non-family firms during the crisis whether I use market performance measure (Tobin's Q) or accounting performance measure (Operating Return on Assets (OROA)). However, family firms with founder presence (as CEO, a board member or a significant blockholder) show significant higher accounting performance by 18 percent relative to non-family firms during the crisis. Market performance of founder firms, by contrast, does not exhibit difference significantly.

Next, I explore the reasons for different findings of founder firms in accounting performance measure and market performance measure. On one hand, OROA computes yearly cash flow over the book value of total assets of a firm, which is less likely to be affected by stock prices. My 
results evidence that during the crisis, compared with non-family firms, founder firms have less administrative costs incurred. Moreover, they invest significantly less and have better access to credit market. All these findings explain the superior accounting performance of founder firms during the crisis.

On the other hand, market performance is measured as Tobin's Q, which is mainly driven by market price of stocks. High volatility of stock prices features as one characteristic of recession times (Veronesi, 1999). In addition, investors are apt to be irrational and to overreact to bad market conditions during recession times (Glode et al., 2010). As a result, high volatility and investors' overreaction may attenuate value premium of founder firms, which enjoy higher market values prior to the crisis comes.

My empirical evidences suggest that founder firms bear the least agency cost compared with other firms during the financial crisis. My results also suggest that during the crisis, when inventors tend to be irrational and stock price volatility is high, Tobin's Q is not a good measure of corporate performance.

The remainder of my paper is structured as follows: Section 2 presents a review of related literature. In Section 3, I describe data and variables. In Section 4, I show my empirical findings with discussions and explanations in Section 5. Finally, I conclude in Section 6. 


\section{Family firms, founder value and financial crisis}

Family firms have been receiving more attentions from academia, policy makers and practioners for at least two reasons: First, family firms prevail in national economy the world around. In US, for example, family firms comprise one-third of the S\&P 500 and account for 18 percent of outstanding shares of capital market (Anderson and Reeb, 2003). Second, family firms, with ownership concentration in most cases, are a good subject for empirically testing various theories like agency theory (Berle and Mean, 1932; Jensen and Meckling, 1976). The key question of family firm research is whether family firms are an effective organizational structure to deliver superior performance relative to non-family firms and what characteristics of family firms determine the performance. Earlier literatures have mixed and inconclusive results regarding this question (Holderness and Sheehan, 1988; McConaughy et al.,1998; Morck et al., 2000; Claessens et al., 2002; Cronqvist and Nilsson, 2003; Anderson and Reeb, 2003).

Current literatures in family business turn to more fine-grained classifications of family firms to reconcile conflicting evidences and tend to agree that performance examination is sensitive to different definitions of family firms (Maury, 2006). Family firms with active founder involvement as CEO or board members predict firm outperformance. Villalongaa and Amit (2006) show that family ownership can gain value only when the founder acts as CEO of the family business or as the Chairman of the board. Similarly, Miller et al. (2007) make a distinction between lone founder businesses where family members of the founder do not involve themselves in management or ownership, and true family businesses where family

members do. The results show that only businesses with a lone founder outperform. By the same token, Adams et al. (2009) identify a positive causal effect of founder-CEOs on firm performance and report that founder-CEOs are more likely to step down from CEO position 
after periods of either unusually low or unusually high operating performances. These researches suggest a positive view of founder value and the necessity of a more fine-grained family firm classification when conducting family business researches.

Although a host of literatures center on performance examination of family firms vis-à-vis non-family firms in normal economic times or good market conditions, studies are almost missing about what the performance will be during depression or recession ages. The current global financial crisis gives us an opportunity of addressing this problem. The extreme market condition (both financial market and product market) during the crisis is more likely amplify various factors that drive the performance of family business, making it unclear whether family firms handle an exogenous financial crisis better on the balance of costs and benefits of family ownership, management and control.

On one hand, asset expropriation of minor shareholders by powerful controlling family shareholder might be more severe during the crisis, which implies that family firms might underperform. Unlike small diversified shareholders, who use market value rules to decide investments that maximize the value of the firms, large family shareholders, may derive greater private benefits from pursuing different investments, excessive compensations, and special dividends given their slumping capital incomes in the crisis (Fama and Jensen, 1985; Andersen and Reeb, 2003). Baek et al. (2003) document that chaebol firms with concentrated shareholding by controlling families have a larger drop in their equity value during 1997 Korea financial crisis. Firms with disproportionate ownership structure (voting rights exceed cash flow rights) also experience lower returns. In addition, family entrenchment and nepotism during the crisis may also hit firm values. Shleifer and Vishny (1997) suggest that one big cost of concentrated family ownership is from remaining unqualified family members to run the firm. Perez-Gonzalez (2006) 
and Bennedsen et al. (2008) evidence the performance drop of family succession, suggesting high costs of nepotism and unqualified family CEOs. During the crisis, when market conditions are harsh, unqualified management may bring more costs to family firms. Using a sample of 800 firms in eight East Asian countries during Eastern Asian financial crisis, Lemmon and Lins (2003) show a significant lower value of firms with entrenchment managers by 10-20 percent relative to other firms ${ }^{1}$.

On the other hand, however, superior performance of family firms might arise from the better alignment of interests between shareholders and managers in family firms (Andersen and Reeb, 2003). Interest conflict between long-term oriented owners and short-term oriented managers is highly costly when a crisis comes. For example, it is well known that managers have the incentive to take excessive risky projects when firm is close to bankruptcy because they get the upside gain of the excess risk but lose nothing from the downside failure. In the crisis, the probability of this situation is high. Moreover, myopic managers may over-invest in projects to boost current performance given the falling sales during the crisis. This is highly risky when financial instruments of the firms are not rich. Dry-out of short term loan from banks with increasingly stringent lending policy might plague ongoing projects. Family firms with large shareholders as managers have no such problem. Villalongaa and Amit (2006) document that founder-CEO firms, free from owner-manager conflict of interests, have the highest Torbin's Q among different types of family firms they have categorized. Another source of outperformance during the crisis might be reputation concerns of family owners with long term commitment to family firms. Chen et al. (2010) find that family firms are less tax aggressive than their non-

\footnotetext{
${ }^{1}$ Asian firms are known for bad Corporate Governance with weak legal protection of investors. Although Baek et al. (2003) and Lemmon and Lins (2003) give evidences of family ownership performance of Asian countries in local financial crisis in 1997, it is doubtable whether these results can apply to firms in Western countries with better Corporate Governance mechanisms and institutional environment.
} 
family counterparts. They interpret the findings as family owners' willingness to forgo tax benefits to avoid the potential penalty and reputation damage from an IRS audit. They also find that firms in need of external capital would exhibit even lower tax aggressiveness. Andersen and Reeb (2003) argue that banks or other financial institutions are more likely to deal with the same governing entities and practices like those in family firms with reputation concerns than in nonfamily firms. During the crisis, when most firms encounter credit constraints, the established relationship with financial institutions could enhance operating performance of firms that do not forgo good investments because of financing problem.

To sum up, whether family firms outperform non-family firms in the financial crisis remains an open empirical question. In the following section, I will provide empirical evidences to investigate this question. 


\section{Data and variables}

\subsection{Sample and sources of data}

The sample consists of a panel of 3,286 firm-year observations, representing 658 firms from S\&P 500 (US), FTE100 (UK), DAX 30 (Germany), CAC 40 (France) and FTSE MIB 40 (Italy) with accounting data from 2006 through 2010. These firms play a vital role in Western industrialized economies. The primary industries of the sample firms span 61 different two-digit SIC codes. Noticing the change of index firm lists during the period 2006-2010, I only include those index firms in the 2011 lists, even if some of them may not stand in the index lists in a particular year.

My data collection process comprises three main phrases. In the first phrase, I compile a dataset to identify blockholders (big shareholders with at least 5 percent of outstanding shares), and board members and top management for each sample firm. I later the dataset use to define family firms. The source of the ownership and board data is Bureau van Dijk Orbis, which covers as many as 78.4 million private and public firms (in 2011) all over the world. It gives me historical ownership structure and information of board members and top managers of the sample firms each year.

In the second phrase, I manually collect information on founding history of each firm from the following sources: (1) company official website; (2) Hoover's; and (3) web search about firm history and family running history. I use the collected information to identify founders, founding families and family member relationships and further to define family firms.

The last phrase is to merge the information from the first two phrases with accounting data from COMPUSTAT and other firm characteristic data (firm age data are from Bureau van Dijk 
Orbis, and market value and stock return data are from Datastream). Table 1 describes the definitions of all variables in my research.

\section{[Inset Table 1 here]}

\subsection{Definitions of different types of family firms}

A key challenge for any analysis regarding family firms is the lack of a widely accepted definition $^{2}$ of what a family firm is (Bennedsen et al., 2010). Previous work has shown that the results of empirical studies are highly sensitive to the choice of the family firm definition (Maury, 2006; Miller et al., 2007). Taking this into account, I manage to involve broad definitions of family firms in my research and scrutinize the possible difference across various types of family firms with my findings. Specifically, my approach of definition covers the following 4 types of family firms:

1. Founder firms, defined as firms in which the founder/founders of the firms holds/hold a position/positions as a board member, or CEO, or a blockholder (at least 5 percent share holding).

2. Heir firms, defined as firms in which the heir/heirs (by blood or by marriage) of the founding family of the firms holds/hold a position/positions either as a board member, or CEO, or a blockholder (at least 5 percent share holding).

3. Family-owned firms, defined as firms in which one individual or several members from the same family together hold more than 10 percent of outstanding shares either directly or indirectly through another family firm or fund which the individual or the family controls or owns.

\footnotetext{
${ }^{2}$ Miller et al. (2007) give a comprehensive review of various definitions of family firms.
} 
4. Leader/owner firms, defined as firms in which the CEO or a board member is simultaneously a significant shareholder with an outstanding ownership stake of at least 5 percent.

When identifying founder(s) and heir(s) of a firm, following Villalonga and Amit (2006), I search from at least two sources of public information. The founder(s) may have founded either one sample firm or a predecessor firm of a sample firm. I regard founder(s) as people responsible for the firm's early growth and development of the business. Therefore, large owners taking control of a firm through a spin-off or a leveraged buyout are not founders in my definition.

When identifying large family firm investors in defining family-owned firms, following Villalonga and Amit (2006), I exclude investment management company investors, such as Fidelity (founded and controlled by Edward Johnson and his daughter, Abigail), or Franklin Resources (founded and controlled by brothers Charles and Rupert Johnson), whose funds act as large institutional investors in the sample firms. I disregard these funds as large family firm investors because the ultimate owners of these funds are a widely dispersed base of diversified investors, not the investment management companies per se.

\subsection{Measure of firm performance}

Following earlier studies, I mean to investigate both market performance and accounting performance of family versus non-family firms during the financial crisis. I use Tobin's Q as the market performance measure and interpret it as a measure of firm value. In my setting, Tobin’s Q is calculated as market value of equity at the end of fiscal year plus book value of total liability (book value of total asset -book value of equity) divided by the book value of total assets at the end of fiscal year. Market value of equity is from Datastream, and book values of total assets and 
equity are from COMPUSTAT. I use Operating Retunes on Assets (OROA) as accounting performance measure. It is Earnings before Interests and Taxes (EBIT) divided by the book values of total assets. Both EBIT and the book value of total assets are from COMPUSTAT. OROA is a natural measure of firm performance because it acts as a comprehensive proxy for a firm's cash flow before interest and taxes relative to its book asset, the earning generator (Bennedsen et al., 2007). Unlike net income-based measure like Return on Assets (ROA), it is unaffected by the variation of capital structure, which determines corporate tax base. Unlike return on equity (ROE), it captures total assets rather than part of it.

\subsection{Descriptive statistics}

Table 2 shows SIC 2-digit industry distribution of the sample firms. Because the main findings of this paper centers on family firms and founder firms, I focus on family firms (column 4), founder firms (column 5) and non-family firms (column 6) in this table. Although family firms are prevalent in economy, they are not symmetrically distributed in every industry. Villalonga and Amit (2006) report family firms are not present in 13 SIC industries, while they are over-represent in some industries. In the sample, I find 11 SIC 2-digit industries are free of family firms. My results of industry representation of family firms are comparable to the findings of Villalonga and Amit (2006) and Anderson and Reeb (2003). In addition, founder firms are concentrated in the industries like electronic and other electrical equipment (SIC 2-digit code: 36) and business service (SIC 2-digit code: 73). These results imply that control industries matters to econometric analysis.

[Insert Table 2 here] 
Table 3 provides the descriptive statistics of main variables of the sample firms in crisis year 2008. All ratio variables are winsorized at 1 percentile and 99 percentile. I again concentrate on family firms, founder firms and non-family firms. Please refer to Appendix 3 for the details of other subgroups of family firms.

Family firms constitute 35 percent of the sample, which is highly consistent with the findings of Villalonga and Amit (2006, 37 percent) and Andersen and Reeb (2003, 35 percent). On average, family firms and founder firms are significantly smaller and less leveraged at 1 percent level relative to non-family firms. The results are consistent with those of Ampenberger et al. (2011) and Villalonga and Amit (2006). The less leverage may imply the risk adverse characteristics of family firms. However, family firms and founder firms invest more and expend more significantly at 1 percent level. More importantly, founder firms exhibit more difference relative to non-family firms in employee number, firm age, research expense and depreciation and amortization. These findings suggest that founder firms are younger firms with less employment, and concentrated in high tech industries, which require intensive research and development investment. In terms of dependent variables OROA and Tobin's Q, I find that founder firms have significantly higher values compared with non-family firms in Tobin's Q, while they do not in accounting performance OROA. The data thus suggest that at the beginning of crisis, family firms as a whole do not outperform non-family firms with respect to Tobin's Q and OROA. However, founder firms, a subgroup of family firms, are better performers in market value but not accounting profit. I early argue that financial crisis has a significant impact on real economy since 2009. The fiscal year choice (2008) may explain the different performance of founder firms in OROA and Tobin's Q relative to non-family firms. Appendix 3 evidences that all the other non-founder family firms: heir firms, family-owned firms and leader/owner firms do 
not exhibit performance superiority relative to non-family firms in both OROA and Tobin's Q. These findings are consistent with those of Miller et al. (2007), suggesting founder firms' value premium. In the next section, I will use multivariate regressions to analyze the performance difference between family firms and non-family firms in a 5 year panel framework, which spans the period before and during crisis, controlling for country, industry, and firm specific characteristics.

[Insert Table 3 here]

\section{Do family firms outperform non-family firms in the financial crisis?}

The principal objective of this paper is to examine whether family firms outperform nonfamily firms during financial crisis, and investigate the reason for the possible outperformance. In this section, I will use several methods to show the main empirical results and to answer the former question.

\subsection{Univariate difference in difference analysis}

I start my analysis with univariate difference in difference test of OROA, and Tobin's Q. Again, I list the 2 performance measures of non-family firms, family firms and founder firms side by side around crisis year in Table 4 .

[Insert Table 4 here]

My first step focuses on comparison between all family firms and non-family firms. I find that both accounting performance and market performance measures are not significantly different expect for tow-year-mean of Tobin's Q before crisis (2006-2007). The performance 
change across crisis for family firms and non-family firms are similar. These results imply that my broadly defined family firm group is not superior performers during financial crisis.

Next, I center on the comparison between founder firms and non-family firms. With respect to accounting performance OROA, the first striking result is that even in crisis, founder firms' OROA does not drop significantly compare with before crisis performance. To be specific, threeyear-mean of OROA before crisis is 0.116 versus 0.111 for two-year-mean during crisis. By contrast, non-family firms during crisis have a profitability shrink by 14 percent, while all family firms 12 percent. Additionally, founder firms significantly outperform non-family firms during crisis by 16 percent, and the performance change across crisis years is also significantly different at 10 percent level. The findings provide the first evidence of founder firms' outperformance during crisis.

The picture of Tobin's Q is somehow different. Although founder firms significantly outperform non-family firms both before and during crisis, the magnitude of outperformance decreases when the crisis shocks firms. Prior to the crisis, founder firms outperform non-family firms by 0.607 in Tobin’s Q. During the crisis, however, founder firms only outperform by 0.380 , which suggests that the financial crisis attenuates market value premium of founder firms. I notice that in the case of accounting performance OROA, the crisis tends to amplify the performance difference between founder firms and non-family firms from 0.005 (before the crisis) to 0.015 (during the crisis). The difference of OROA and Tobin's Q in magnitude change implies that the financial crisis may have a disparate effect on corporate cash flow based performance and market value based performance. I would use multivariate regressions to scrutinize the difference in the next section. 


\subsection{Firm fixed effect estimation}

First, I use firm fixed effect model to test whether family firms outperform non-family firms during crisis. The econometric model is as follows ${ }^{3}$ :

$$
Y_{i t}=\alpha+\beta_{0} \text { Family }_{i} * \text { Crisis }_{i t}+\beta_{1} \text { Crisis }_{i t}+X_{i t-1}^{\prime} \beta_{2}+u_{i}+e_{i t}
$$

Where $Y_{i t}$ is performance measure, referring to OROA or Tobin's Q. Family is a dummy which equals one if one firm is a family firm. Crisis ${ }_{i t}$ is a dummy, denoting either Crisis_acc, which equals one if fiscal year is 2009 and 2010, or Crisis_mkt, which equals one if fiscal year is 2008, 2009 and 2010. Family ${ }_{i}{ }^{*}$ Crisis $_{i t}$ is an interaction variable. $\beta_{0}$ is my interested coefficient. $u_{i}$ is the firm fixed effect, and $e_{i t}$ is error term, $X_{i t-1}^{\prime}$ is a vector of lagged control variables ${ }^{4}$. Following Andersen and Reeb (2003), Villalonga and Amit (2006) and Miller et al. (2007), I incorporate several control variables into my model: Firm size is the natural logarithm of the book value of total assets. Growth opportunities and advertising expense ${ }^{5}$ are measured as research and development expenses over sales and advertising expense over sales respectively. Return volatility the proxy for firm risk, calculated as the standard deviation of monthly stock returns for the last 36 months. Capital structure is the ratio of debt to total assets. Investment is the capital expenditure over plant, property and equipment (PPE) at the end of last fiscal year. I also include firm age, and natural logarithm of employee number.

\footnotetext{
3 Following earlier researches, I define variable Family $_{i}$, Founder Heir $_{i}$, Family_owned Fi $_{\text {and }}$

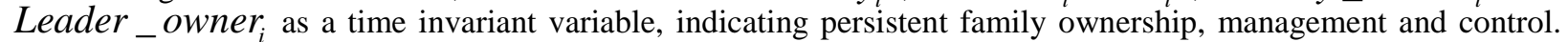
Because firm fixed effects absorb all firm level time-invariant effect, I drop the variable Family ${ }_{i}$ from my fixed effect model. The firm fixed effect specification is also supported by Hausman test.

${ }^{4}$ I use lagged control variables to control for contemporary feedback effects between dependent variables and control variables.

${ }^{5}$ Following Millers et al., I code missing data as 0, because corporations have to report significant expenditures by law.
} 
Table 5 illustrates that after controlling for firm fixed effect, and time-variant firm specific characteristics, family firms, as broadly defined in the sample, do not significantly outperform non-family firms during the crisis. The insignificance is similar whether I use OROA or Tobin's Q as performance measure and consistent with early univariate analysis.

[Insert Table 5 here]

Next, I split family firms into 4 subgroups and involve 4 dummies in the fixed effect model. I aim to examine whether different groups perform differently during the crisis. The model I use is as follows:

$Y_{i t}=\alpha+\beta_{0}$ Crisis $_{i t}+\beta_{1}$ Founder $_{i}^{*}$ Crisis $_{i t}+\beta_{2}$ Heir $_{i} *$ Crisis $_{i t}+$ $\beta_{3}$ Family_owned $_{i} *$ Crisis $_{i t}+\beta_{4}$ Leader_owner $_{i} *$ Crisis $_{i t}+X_{i t-1}^{\prime} \beta_{5}+u_{i}+e_{i t}$

Where $Y_{i t}$ is performance measure, referring to OROA or Tobin's Q. Founder ${ }_{i}$ Heir $_{i}$ Family_owned ${ }_{i}$ and Leader_owner ${ }_{i}$ are a dummy which equals one if one firm is a founder firm, heir firm, family-owned firm and leader/owner firm respectively. Crisis ${ }_{i t}$ is a dummy, denoting either Crisis_acc, which equals one if fiscal year is 2009 and 2010, or Crisis_mkt, which equals one if fiscal year is 2008, 2009 and 2010. Founder ${ }_{i}^{*}$ Crisis $_{i t}$, Heir $_{i}{ }^{*}$ Crisis $_{i t}$, Family_owned $_{i} *$ Crisis $_{i t}$, and Leader_owner ${ }_{i} *$ Crisis $_{i t}$ are interactions variable. $\beta_{1}$ to $\beta_{4}$ are my interested coefficients. $X_{i t-1}^{\prime}$ is the same vector of lagged control variables as model (1). $u_{i}$ is the firm fixed effect. $e_{i t}$ is an error term.

Table 6 exhibits disparate pictures for accounting performance OROA and market performance Tobin'Q. Only founder firms show significantly superior performance in OROA 
during the financial crisis, while they do not in Tobin's Q. In the case of OROA, the positive coefficient of Founder is significant at 5 percent level. It means on average, founder firms outperform non-family firms by 2 percent OROA during crisis. The magnitude of outperformance accounts for as high as 18 percent of the mean OROA of non-family firms in 2009 and 2010. In contrast, when controlling for firm fixed effect and other time-varying factors, founder firms do not exhibit significant value premium, measured in Tobin's Q during the crisis. These results complement the works of Andersen and Reeb (2003), Villalonga and Amit (2006) and Maury (2006), and Miller et al. (2007) by providing new evidence suggesting that in recession times, market value premium of founder firms disappears, whereas accounting performance premium displays.

[Insert Table 6 here]

\subsection{Endogeneity of founder status and other robustness tests}

Although fixed effect estimation controls for unobservable time-invariant heterogeneity, time-variant heterogeneity may bias the estimates. Founder status is not randomly assigned to sample firms. I am unable to indentify an unbiased and consistent estimator, given underlying omitted determinants of selection into founder firms are correlated to outcome performances. Following Maury (2006), Villalonga and Amit (2006) and Miller et al. (2007), I adopt Heckman's two step treatment effect model ${ }^{6}$ to tackle this issue.

The first step is to run a Probit regression of founder status on various controls used for the second treatment regression, plus two other variables: sales growth (Villalonga and Amit, 2006),

\footnotetext{
${ }^{6}$ Similar to Maury (2006) and Fahlenbrach (2009), I prefer Heckman's (1979) model to standard 2SLS estimator model because it estimates a Probit regression in the first stage, allowing for the dichotomous nature of the dummy Founder.
} 
and cash holdings (Miller and Le Breton-Miller, 2005) to distinguish among founder firms and other firms. To meet exclusion restriction of identification, I add two more instruments to the first stage. The first instrument is Old firm, which is one if a firm is incorporated before 1960 . Fahlenbrach (2009) first introduces this instrument ${ }^{7}$ to analyze founder-CEO effect on investment and stock market performance. A firm set up before 1960 is most unlikely to have its founder(s) present at the firm given the average age of founder firms is 29 in my sample. The second instrument is US, equaling one if the headquarter of a sample firm is in the US. In my sample, as high as 82 percent of founder firms are US firms. When these two instruments are strongly correlated to founder firms, they have slim chance of affecting operating performance beyond the control variables in the second step treatment regression, whose econometric model is as follows:

$Y_{i}=\alpha+\beta_{0}$ Founder $_{i}+\beta_{1}$ Heir $_{i}+\beta_{2}$ Family_owned $_{i}+\beta_{3}$ Leader_owner $_{i}+X_{i}^{\prime} \beta_{4}+e_{i}$ (3)

Where $Y_{i t}$ is the difference between average OROA of the period 2009-2010 and average OROA of the period 2006-2008. Founder ${ }_{i}$ Heir $_{i}$ Family_owned $_{i}$ and Leader_owner ${ }_{i}$ are a dummy which equals one if one firm is a founder firm, heir firm, family-owned firm and leader/owner firm respectively. $\beta_{0}$ is my interested coefficient. $X_{i}^{\prime}$ is a vector of control variables of fiscal year 2008. It includes firm size, growth opportunities, advertising expense firm risk, capital structure, firm age, and employee number. $e_{i}$ is an error term.

In Table 7, the first-stage regression shows that founder firms are negatively related to Old firms, while positively related to US dummy and Ln cash, implying the legitimacy of instruments.

\footnotetext{
${ }^{7}$ Fahlenbrach uses 1940 as a threshold of old firms. However, his sample period is from 1995 to 2002. In my case, I use 1960 since my sample period is from 2006 to 2010.
} 
In the second stage treatment regression, the coefficient of Founder is 0.047 , significant at 5 percent level. The finding is consistent with that of former fixed effect model. The lambda statistic is statistically significant at 10 percent level, supporting existence of selection bias. Taken together, Heckman’s model confirms founder firms’ outperformance during the crisis.

[Insert Table 7 here]

As an alternative robustness test, I exclude financial firms from my sample and re-run firm fixed effect regressions. The results are consistent with those of full sample. The magnitude of coefficients highly resembles that from full sample fixed effect model(Please refer to Appendix 4 for details).

I conclude this section by stating that when the financial crisis comes, broadly defined family firms are not superior performers. However, founder firms outperform during the crisis in terms of accounting measure OROA. Interestingly, market value premium of founder firms, which is widely documented in normal or good economic times in earlier studies, disappears. I will explain the phenomena in the next section.

\section{Why do founder firms outperform in accounting profitability, not in market valuation?}

I start to explain the different performance of founder firms with respect to OROA and Tobin's Q during the financial crisis by analyzing the different algorithms of these two measures. OROA is a period cash flow divided by the book value of total assets at the end of a fiscal year. Therefore, it is a revenue based profitability measure driven by business strategy, operating efficiency, management skills, expense control and other firm level characteristics. On the 
contrary, Tobin's Q is computed as market value over book value of total assets. Because book value of a firm is persistent, Tobin's Q is mainly driven by market price of stocks (I use book value of total liability of debt plus market value of stocks as a proxy for market value of total assets). A large body of financial literature documents high volatility of stocker returns in recession times (for example, Veronesi, 1999). Table 8 clearly evidences that during the crisis, volatility of monthly returns is as high as 12 percent, while only 6 percent in normal times. Economists tend to attribute high volatility to investors' uncertainty about the future growth of economy in bad times. In addition, investors are prone to be irrational and they overreact to bad market conditions during recessions (Glode et al., 2010). In my context, I argue that in the recent financial crisis, high volatility tends to attenuate value premium of founder firms given investors' overreaction to bad market conditions and undervaluing stock prices. Univariate difference in difference analysis in Table 4 also supports my argument. Before crisis, market value premium of founder firms is 0.607 and during crisis, it declines to 0.380 by 35 percent. Moreover, market value drop before and during the crisis is 0.449 for non-family firms versus 0.664 for founder firms. Return volatility for founder firms in the crisis year 2008 is 0.112 , significantly higher than non-family firms (0.098) in Table 3. I therefore ascribe founder firm value premium vanishing to investors' irrational overreaction to bad market conditions and high volatility during recession times.

Next, I explain the reasons for accounting performance premium for founder firms during the crisis. I split OROA into 4 components according to the calculation formula:

OROA $=$ EBIT/total assets $=$ Sales/total assets - Costs of goods/total assets - Admin expense/total assets - Depreciation and Amortization/total assets. 
[Insert Table 9 here]

I use firm fixed effect model similar to model (2) to examine which component(s) contribute(s) the performance premium of founder firms during the crisis. The results in Table 9 show that among 4 components, only expense/total assets of founder firms is significantly lower during the crisis at 10 percent level. This suggests that founder firms do a better job in administrative expense control in the crisis, which results in a net profit premium. Previous studies (Morck et al., 1988, 2000; Fahlenbrach, 2005, etc.) argue that founders bring differentially valuable skills to firms. "Founders may be inspiring leaders, great visionaries, or exceptionally talented scientists." (Villalonga and Amit, 2006). My findings suggest that in additional to above mentioned skills, founders serve as good expense controllers, leading firms to survive recession ages.

Besides efficient expense control during the crisis, I use fixed effect model to investigate other financial and investment strategy difference between founder firms and non-family firms, which may also affect accounting performance. I test the difference in capital structure, short term debt change, and ratio of capital expenditure to PPE between founder firms and non-family firms, controlling for multi variables ${ }^{8}$. Table 10 presents the results.

\section{[Insert Table 10 here]}

I find that founder firms invest significantly less (at 5 percent level) relative to non-family firms in the crisis. At the same time, however, founder firms have gained more short term loan and aggregate level of debt is higher than non-family firms. The coefficients of Founder*crisis_acc in both regressions mean (column 2 and 3) that on average, founder firms

\footnotetext{
${ }^{8}$ For the regression of investment, I follow Elull et al. (2010) to choose control variables. For the regression of capital structure and short term debt change, I follow Antoniou et al. (2008) to choose control variables.
} 
during the crisis have a bigger increment of short term debt by 431 mil US dollars relative to non-family firms and their capital structure is more leveraged by 0.8 relative to non-family firms. Recall that in Table 3 descriptive statistics, before crisis $^{9}$ founder firms are less leveraged and invest more relative to non-family firms. The coefficients indicate that founder firms substantially change their investment and financial strategy during the crisis. I also find that cash flow and working capital of founder firms are similar to those of non-family firms ${ }^{10}$. If I assume that more short term debt means better access to credit market, the fact of founder firms raise their debt level during the crisis suggests that founders firms have more financing resources than non-family firms in bad time, when financial institutions tighten credit granting. I do not want draw too strong conclusion that it is the founders who play a pivotal role in abundant debt access. But the association between founder firms and higher leverage during the crisis may imply extra skills and resources related to the founders.

In summary, I argue that during the financial crisis, founder firms have a better control of expense and make a more conservative investment strategy even though they may get better access to credit market than their counterparts. All these findings explain the superior accounting performance of founder firms. By contrast, because market performance are mainly driven by stock prices, high volatility of stock returns and investors’ overreaction to bad market conditions during the crisis may dilute market value premium of founder firms.

\footnotetext{
${ }^{9} 2008$ is viewed as before the crisis for accounting performance examinations.

${ }^{10} \mathrm{I}$ also test the difference in working capital and cash between founder firms and non-family firms to examine firm short term financing instruments change, which may affect operating performance. However, I do not find significant differences.
} 


\section{Concluding remarks}

It is the prevalence of family firms all over the world that makes academics pay increasing attention to family business researches. One central issue is to examine whether family firms are a superior organizational structure. Although a growing body of literature has made rigorous performance analyses between family firms and non-family firms in normal or good economic times, rather scant papers try to investigate the topic in recession times. This paper attempts to fill this knowledge void.

Constructing a detailed dataset from proxy filings of firms from S\&P 500 (US), FTE100 (UK), DAX 30 (Germany), CAC 40 (France) and FTSE MIB 40 (Italy) from 2006 through 2010, I target contributing to the literature by conducting a performance comparison between family firms and non-family firms during the current financial crisis.

I find that family firms, as broadly defined, comprise 35 percent of the sample firms. They do not significantly outperform non-family firms during the crisis whether I use market value measure (Tobin’s Q) or accounting profitability measure (OROA). However, founder firms, as a subgroup of family firms significantly outperform non-family firms by 18 percent in accounting profitability measure during the crisis. Market performance of founder firms, by contrast, do not

exhibit difference significantly. My interpretation of this phenomenon is that Tobin's Q is mainly driven by stock prices. High volatility and investors' overreaction during the crisis (Veronesi, 1999; Glode et al., 2010) may attenuate market value premium of founder firms.

Further testing shows that during the crisis, relative to non-family firms, founder firms have less administrative costs incurred. Moreover, they invest significantly less and have better access 
to credit market. All these findings determine the superior accounting performance of founder firms during the crisis.

Taken as a whole, my results support widely-documented "founder premium” (for instance, Morck et al., 1988, 2000; Fahlenbrach, 2004). Founders not only bring valuable skills in normal economic times, but also enable firms to weather financial crisis with better expense control, more financial resource and conservative investment strategy. My results suggest that agency cost in founder firms is the least relative to other firms during recession times. The results also suggest that when inventors tend to be irrational and stock price volatility is high, Tobin's $Q$ is not a good measure of performance. 


\section{References:}

Adams, R., H. Almeida, and D. Ferreira. (2009). "Understanding the Relationship between Founder-CEOs and Firm Performance.” Journal of Empirical Finance 16 (1): 136-50.

Ampenberger,M., M. Bennedsen, and H.Y. Zhou (2011). “Capital Structure of Family firms.” In Cumming, D. (Ed.), Oxford Handbook of Entrepreneurial Finance. Oxford University Press. Forthcoming.

Anderson, R. C., and D. M. Reeb. (2003). Founding-family Ownership and Firm Performance: Evidence from the S\&P 500.” Journal of Finance 58: 1301-28.

Anderson R. and D.M. Reeb. (2003). "Founding-family Ownership, Corporate Diversification, and Firm Leverage”. Journal of Law and Economics 46 (2): 653-684.

Antoniou A., Y. Guney, and K. Paudyal. (2008). “The Determinants of Capital Structure: Capital Market-Oriented versus Bank-Oriented Institutions.” Journal of Financial and Quantitative Analysis 43(1): 59-92.

Baek, J., J.K. Kang, and K.S.Park. (2004). “Corporate Governance and Firm Value: Evidence from the Korean Financial Crisis.” Journal of Financial Economics 71: 265-313.

Bennedsen, Morten, K. Nielsen, F. Pérez-González and D. Wolfenzon. (2007). “Inside the Family Firm: The Role of Families in Succession Decisions and Performance.” The Quarterly Journal of Economics 122 (2): 647-691.

Bennedsen, M. and Nielsen, Kasper, M., (2010), “Incentive and Entrenchment Effects in European Ownership”, Journal of Banking and Finance 34: 2212-2229. 
Berle, A., Means, G., (1932). The Modern Corporation and Private Property. Harcourt, Brace, \& World, New York, NY.

Bertrand, M., S. Johnson, K. Samphantharak, and A. Schoar. (2008). "Mixing Family with Business: A Study of Thai Business Groups and the Families behind Them.” Journal of Financial Economics 88: 466-498.

Chen, S., X. Chen, Q. Cheng, and T. Shevlin. (2010). “Are Family Firms More or Less Tax Aggressive? ”Journal of Financial Economics 95 (1): 41-61.

Claessens, S., S. Djankov, and L. H. P. Lang. (2000). "Separation of Ownership from Control of East Asian Firms.” Journal of Financial Economics 58:81-112.

Claessens, S., S. Djankov, J.P.H. Fan, L.H.P. Lang. (2002). Disentangling the Incentive and Entrenchment Effects of Large Shareholdings. Journal of Finance 57: 2741-2772.

Coase, R. (1937). “The Nature of the Firm.” Economica 4 (16): 386-405.

Coase, R. (1960). “The Problem of Social Cost.” Journal of Law and Economics 3 (1): 1-44.

Cronqvist, H., M. Nilsson. (2003). “Agency Costs of Controlling Minority Shareholders.” Journal of Financial and Quantitative Analysis 38: 695-719.

Diamond, D. W., and R. Rajan. (2000). “Banks, Short Term Debt and Financial Crises: Theory, Policy Implications and Applications.” NBER working paper.

Demsetz, H. (1983). “The Structure of Ownership and the Theory of the Firm.” Journal of Law and Economics 26: 375-390. 
Demsetz, H., K. Lehn. (1985). “The Structure of Corporate Ownership: Causes and Consequences.” Journal of Political Economy 93: 1155-1177.

Demsetz, H., B. Villalonga. (2001). “Ownership Structure and Corporate Performance.” Journal of Corporate Finance 7: 209-233.

Ellul, A., M. Pagano, and F. Panunzi, "Inheritance Law and Investment in Family Firms.” American Economic Review 100(5): 2414-2450.

Faccio, M., L.H.P. Lang. (2002). “The Ultimate Ownership of Western European Corporations.” Journal of Financial Economics 65: 365-395.

Fahlenbrach, R., 2005. ”Founder-CEOs and Stock Market Performance.” Unpublished working paper. Wharton School, University of Pennsylvania.

Fama, Eugene, and M. Jensen, (1985). “Organizational forms and investment decisions.” Journal of Financial Economics 14:101-119.

Glode,V., B. Hollifield, M. Kacperczyk, and S. Kogan. (2010). “Is Investor Rationality Time Varying? Evidence from the Mutual Fund Industry.” NBER working paper.

Heckman, J.J., (1979). “Sample Selection Bias as a Specification Error.” Econometrica 47: 153161.

Holderness, C.G., Sheehan, D.P., 1988. The role of majority shareholders in publicly held corporations. Journal of Financial Economics 20, 317-346.

Jensen, M.C., W. Meckling. (1976). “Theory of the Firm: Managerial Behavior, Agency Costs and Ownership Structure.” Journal of Financial Economics 3: 305-360. 
Klein, S. B. (2000). “Family Businesses in Germany: Significance and Structure.” Family Business Review, 13(3): 157-181.

La Porta, R., F. Lopez-De-Silanes, A. Shleifer. (1999). “Corporate Ownership around the World.” Journal of Finance 54: 471-517.

La Porta, R., F. Lopez-de-Silanes, A. Shleifer, R. Vishny. (2002). "Investor Protection and Corporate Valuation. ”Journal of Finance 57 (3): 1147-1170.

Lemmon, M., K. Lins. (2003). “Ownership Structure, Corporate Governance, and Firm Value: Evidence from the East Asian Financial Crisis.” Journal of Finance 58(4): 1445-1468.

Li, F., and S. Srinivasan. (2010). “Corporate Governance When Founders Are Directors.” Journal of Financial Economics, forthcoming.

Maury, B. (2006). “Family Ownership and Firm Performance: Empirical Evidence from Western European Corporations.” Journal of Corporate Finance 12 (2): 321-41.

McConaughy, D.L., M.C. Walker, Jr. G.V. Henderson and C.S. Mishra. (1998). “Founding Family Controlled Firms: Efficiency and Value.” Review of Financial Economics 7: 1-19.

Miller, D., I. Le Breton-Miller, R. H. Lester, and A. A. Cannella Jr. (2007). “Are Family Firms Really Superior Performers?” Journal of Corporate Finance 13 (5): 829-858.

Mitton, T. (2002). “A Cross-firm Analysis of the Impact of Corporate Governance on the East Asian Financial Crisis.” Journal of Financial Economics 64: 215-241.

Morck, R.K.,A. Shleifer, R. Vishny. (1988). "Management Ownership and Market Valuation: An Empirical Analysis.” Journal of Financial Economics 20: 293-315. 
Morck, R.K., D. A. Stangeland, B. Yeung. (2000). “Inherited Wealth, Corporate Control, and Economic Growth. The Canadian Disease?” In: Morck, R.K. (Ed.), Concentrated Corporate Ownership. University of Chicago Press, Chicago, IL: 319-369.

Morck, R.K., B. Yeung. (2003). “Agency Problems in Large Family Business Groups.” Entrepreneurship Theory and Practice 27: 367 - 382.

Perez-Gonzalez, Francisco. (2006). “Inherited Control and Firm Performance” American Economic Review 96: 1559-1588.

Shleifer, A. and R. Vishny. (1997). “A survey of corporate governance”, Journal of Finance 52: 737-783.

Veronesi, P. (1999). "Stock Investors Overreaction to Bad News in Good Times: A Rational Expectation Equilibrium Model.” Review of Financial Studies 12 (5): 975-1007.

Villalonga, B., and R. Amit. (2006). "How Do Family Ownership, Control and Management Affect Firm Value?” Journal of Financial Economics 80 (2): 385-417.

Villalonga, B., and R. Amit. (2009). “How are US Family Firms Controlled?” Review of Financial Studies 22 (8): 3047-3091. 
Table 1 Variable definitions

\begin{tabular}{|c|c|}
\hline Variables & Definition \\
\hline Crisis_acc & $\begin{array}{l}\text { Accounting crisis year, a dummy variable, which is one if the fiscal } \\
\text { year is } 2009 \text { and } 2010 \text {. This variable indicates the years when } \\
\text { financial crisis significantly strikes real economy }{ }^{11} \text {. }\end{array}$ \\
\hline Crisis_mkt & $\begin{array}{l}\text { Market crisis year, a dummy variable, which is one if fiscal year is } \\
2008,2009 \text { and } 2010 \text {. This variable indicates the years when } \\
\text { financial crisis significantly strikes the financial market. }\end{array}$ \\
\hline Family & $\begin{array}{l}\text { A dummy variable, which is one if the sample firm is a family firm. } \\
\text { Family firms are the sum of all the four subgroups of firms: (1) } \\
\text { founder firms; (2) heir firms; (3) family-owned firms; and (4) } \\
\text { Leader/owner firms. Please refer to the definitions of the four } \\
\text { subgroups of family firms below. }\end{array}$ \\
\hline Founder & $\begin{array}{l}\text { Founder firms, a dummy variable, which is one if the } \\
\text { founder/founders of the firm holds/hold a position as a board } \\
\text { member, or CEO, or a blockholder (at least } 5 \text { percent share } \\
\text { holding). }\end{array}$ \\
\hline Heir & $\begin{array}{l}\text { Heir firms, a dummy variable, which is one if the heir/heirs (by } \\
\text { blood or by marriage) of the founder/founders of the firm } \\
\text { holds/hold a position either as a board member, or CEO, or a } \\
\text { blockholder (at least } 5 \text { percent share holding). }\end{array}$ \\
\hline Family_owned & $\begin{array}{l}\text { Family-owned firms, a dummy variable, which is one if one } \\
\text { individual or several members from the same family together hold } \\
\text { more than } 10 \text { percent of outstanding shares either directly or } \\
\text { indirectly through another family firm or fund which the individual } \\
\text { or the family controls or owns. }\end{array}$ \\
\hline Leader_owner & $\begin{array}{l}\text { Leader/owner firms, a dummy variable, which is one if the CEO or } \\
\text { a board member is simultaneously a significant shareholder with an } \\
\text { outstanding ownership stake of at least } 5 \text { percent. }\end{array}$ \\
\hline OROA & $\begin{array}{l}\text { Operating Retunes on Assets, defined as earnings before interests } \\
\text { and taxes (EBIT) divided by the book values of total assets. }\end{array}$ \\
\hline Tobin's Q & $\begin{array}{l}\text { Market value of equity plus book value of total liability (book value } \\
\text { of total asset -book value of equity) divided by the book value of } \\
\text { total assets. }\end{array}$ \\
\hline Difference in OROA & $\begin{array}{l}\text { The difference between average OROA of the period 2009-2010 } \\
\text { and average OROA of the period 2006-2008. }\end{array}$ \\
\hline Size & $\begin{array}{l}\text { Firm size, defined as the natural logarithm of the book value of total } \\
\text { assets of a firm. }\end{array}$ \\
\hline
\end{tabular}

\footnotetext{
${ }^{11}$ The bankruptcy of Lehman Brother in September 222008 signals the coming of current financial crisis. Financial market reacts immediately to the event of bankruptcy and stock prices slump. Appendix 1 evidences this picture. I therefore define market crisis years as year 2008, 2009 and 2010. However, the reaction of real economy lags behind the financial market. The crisis has a significant effect on real economy since 2009, which is supported by the national GDP growth rate in Appendix 2. So I define accounting crisis years as year 2009 and 2010.
} 


\begin{tabular}{|c|c|}
\hline & Table 1 , continued \\
\hline Capital Structure & $\begin{array}{l}\text { Debt to equity ratio, defined as the book value of total liability } \\
\text { (book value of total asset - book value of equity) divided by the } \\
\text { book value of total equity. }\end{array}$ \\
\hline Investment & $\begin{array}{l}\text { Ratio of Capital expenditure to Plant, Property and Equipment } \\
\text { (PPE), defined as capital expenditure divided by the PPE of last } \\
\text { fiscal year. }\end{array}$ \\
\hline Ln employee & Natural logarithm of the number of employees the firm. \\
\hline ROA & $\begin{array}{l}\text { Returns on Assets, defined as net income divided by the book value } \\
\text { of total assets. }\end{array}$ \\
\hline Working capital growth & $\begin{array}{l}\text { Yearly working capital growth rate, defined as increment of yearly } \\
\text { working capital divided by working capital of last fiscal year. }\end{array}$ \\
\hline Short debt change & $\begin{array}{l}\text { Yearly short term debt increment, defined as the difference between } \\
\text { short term debt this fiscal year and last fiscal year, measured in } 1 \\
\text { billion US dollars. }\end{array}$ \\
\hline Advertising & $\begin{array}{l}\text { Adverting expense, defined as yearly advertising expense divided } \\
\text { by sales. }\end{array}$ \\
\hline Research & $\begin{array}{l}\text { Research and development expense, defined as yearly research and } \\
\text { development expense divided by sales. }\end{array}$ \\
\hline Firm age & The difference between incorporation year and a fiscal year. \\
\hline Return volatility & $\begin{array}{l}\text { Firm idiosyncratic risk, defined as the standard deviation of stock } \\
\text { returns for the previous } 36 \text { months. }\end{array}$ \\
\hline Ln cash & Natural logarithm of cash. \\
\hline Sales growth rate & $\begin{array}{l}\text { Yearly sales growth rate, defined as increment of yearly total sales } \\
\text { divided by total sales of last fiscal year. }\end{array}$ \\
\hline Tangibility & $\begin{array}{l}\text { Tangible assets, defined as tangible assets divided by the book } \\
\text { values of total assets. }\end{array}$ \\
\hline Profitability & Lagged OROA, Operating Return on Assets of last fiscal year. \\
\hline Dividend payout & Dividend divided by sales. \\
\hline Non-debt tax shield & $\begin{array}{l}\text { Depreciation and amortization divided by the book value of total } \\
\text { assets. }\end{array}$ \\
\hline Old firm & $\begin{array}{l}\text { A dummy variable, which is one if the sample firm is incorporated } \\
\text { before } 1960 .\end{array}$ \\
\hline US & $\begin{array}{l}\text { A dummy variable, which is one if the headquarter of a sample firm } \\
\text { is in the US. }\end{array}$ \\
\hline Sales/asset & Ratio of sales to the book value of total assets. \\
\hline Expense/asset & $\begin{array}{l}\text { Ratio of selling, general administrative expense to the book value of } \\
\text { total assets. }\end{array}$ \\
\hline Cost/asset & Ratio of costs of goods to the book value of total assets. \\
\hline Depreciation/asset & $\begin{array}{l}\text { Ratio of depreciation and amortization to the book value of total } \\
\text { assets. }\end{array}$ \\
\hline
\end{tabular}


Table 2 Industry distribution of family firms, founder firms and non-family firms

\begin{tabular}{|c|c|c|c|c|c|c|c|}
\hline $\begin{array}{l}\text { SIC } \\
\text { code }\end{array}$ & Industry description & $\begin{array}{c}\text { All } \\
\text { firms }\end{array}$ & $\begin{array}{l}\text { Family } \\
\text { firms }\end{array}$ & $\begin{array}{l}\text { Founder } \\
\text { firms }\end{array}$ & $\begin{array}{l}\text { Non- } \\
\text { family } \\
\text { firms }\end{array}$ & $\begin{array}{l}\text { \% family } \\
\text { firms in the } \\
\text { industry }\end{array}$ & $\begin{array}{l}\% \text { founder } \\
\text { firms in the } \\
\text { industry }\end{array}$ \\
\hline 10 & Metal mining & 11 & 6 & 1 & 5 & $55 \%$ & $9 \%$ \\
\hline 12 & Coal mining & 5 & 0 & 0 & 5 & $0 \%$ & $0 \%$ \\
\hline 13 & Oil and gas extraction & 29 & 10 & 6 & 19 & $34 \%$ & $21 \%$ \\
\hline 14 & $\begin{array}{l}\text { Mining and quarrying of nonmetallic } \\
\text { minerals, except fuels }\end{array}$ & 1 & 0 & 0 & 1 & $0 \%$ & $0 \%$ \\
\hline 15 & General building contractors & 6 & 5 & 2 & 1 & $83 \%$ & $33 \%$ \\
\hline 16 & Heavy construction, except buildings & 3 & 2 & 0 & 1 & $67 \%$ & $0 \%$ \\
\hline 17 & Special trade contractors & 1 & 0 & 0 & 1 & $0 \%$ & $0 \%$ \\
\hline 20 & Food and kindred products & 27 & 14 & 0 & 13 & $52 \%$ & $0 \%$ \\
\hline 21 & Tobacco products & 6 & 2 & 0 & 4 & $33 \%$ & $0 \%$ \\
\hline 23 & Apparel and other textile products & 3 & 1 & 0 & 2 & $33 \%$ & $0 \%$ \\
\hline 24 & Lumber and wood products & 2 & 1 & 0 & 1 & $50 \%$ & $0 \%$ \\
\hline 25 & Furniture and fixtures & 2 & 1 & 0 & 1 & $50 \%$ & $0 \%$ \\
\hline 26 & Paper and allied products & 6 & 0 & 0 & 6 & $0 \%$ & $0 \%$ \\
\hline 27 & Printing and publishing & 5 & 2 & 0 & 3 & $40 \%$ & $0 \%$ \\
\hline 28 & Chemical and allied products & 49 & 16 & 1 & 33 & $33 \%$ & $2 \%$ \\
\hline 29 & Petroleum and coal products & 8 & 2 & 0 & 6 & $25 \%$ & $0 \%$ \\
\hline 30 & Rubber and miscellaneous plastic products & 6 & 2 & 1 & 4 & $33 \%$ & $17 \%$ \\
\hline 31 & Leather and leather products & 1 & 1 & 0 & 0 & $100 \%$ & $0 \%$ \\
\hline 32 & Stone, clay, and glass products & 7 & 4 & 0 & 3 & $57 \%$ & $0 \%$ \\
\hline 33 & Primary metal industries & 11 & 6 & 2 & 5 & $55 \%$ & $18 \%$ \\
\hline 34 & Fabricated metal products & 5 & 0 & 0 & 5 & $0 \%$ & $0 \%$ \\
\hline 35 & Industrial machinery and equipment & 24 & 8 & 4 & 16 & $33 \%$ & $17 \%$ \\
\hline 36 & Electronic and other electrical equipment & 37 & 15 & 9 & 22 & $41 \%$ & $24 \%$ \\
\hline 37 & Transportation equipment & 21 & 6 & 0 & 15 & $29 \%$ & $0 \%$ \\
\hline 38 & Instruments and related products & 35 & 10 & 2 & 25 & $29 \%$ & $6 \%$ \\
\hline 39 & Miscellaneous manufacturing products & 4 & 1 & 0 & 3 & $25 \%$ & $0 \%$ \\
\hline 40 & Railroad transportation & 3 & 0 & 0 & 3 & $0 \%$ & $0 \%$ \\
\hline 42 & Trucking and warehousing & 1 & 1 & 0 & 0 & $100 \%$ & $0 \%$ \\
\hline 44 & Water transportation & 2 & 2 & 0 & 0 & $100 \%$ & $0 \%$ \\
\hline 45 & Transportation by air & 4 & 1 & 1 & 3 & $25 \%$ & $25 \%$ \\
\hline 46 & Pipelines, except natural gas & 1 & 0 & 0 & 1 & $0 \%$ & $0 \%$ \\
\hline 47 & Transportation services & 5 & 3 & 0 & 2 & $60 \%$ & $0 \%$ \\
\hline 48 & Communications & 29 & 14 & 6 & 15 & $48 \%$ & $21 \%$ \\
\hline 49 & Electric, gas, and sanitary services & 55 & 2 & 0 & 53 & $4 \%$ & $0 \%$ \\
\hline 50 & Wholesale trade of durable goods & 7 & 3 & 1 & 4 & $43 \%$ & $14 \%$ \\
\hline 51 & Wholesale trade of nondurable goods & 8 & 2 & 2 & 6 & $25 \%$ & $25 \%$ \\
\hline 52 & Building materials and gardening & 3 & 1 & 0 & 2 & $33 \%$ & $0 \%$ \\
\hline 53 & General merchandise stores & 13 & 7 & 2 & 6 & $54 \%$ & $15 \%$ \\
\hline 54 & Food stores & 6 & 3 & 0 & 3 & $50 \%$ & $0 \%$ \\
\hline 55 & Auto dealers and service stations & 3 & 2 & 0 & 1 & $67 \%$ & $0 \%$ \\
\hline 56 & Apparel and accessory stores & 8 & 4 & 3 & 4 & $50 \%$ & $38 \%$ \\
\hline 57 & Furniture and home furnishings & 4 & 2 & 2 & 2 & $50 \%$ & $50 \%$ \\
\hline 58 & Eating and drinking places & 6 & 1 & 0 & 5 & $17 \%$ & $0 \%$ \\
\hline 59 & Miscellaneous retail & 7 & 3 & 2 & 4 & $43 \%$ & $29 \%$ \\
\hline
\end{tabular}


60 Depository institutions

61 Nondepository institutions

62 Security and commodity brokers

63 Insurance carriers

64 Insurance agents, brokers, services

65 Real estate

67 Holding And Other Investment Offices

70 Hotels and other lodging places

72 Personal services

73 Business services

75 Auto repair, services, and parking

78 Motion pictures

79 Amusement and recreation services

80 Health services

82 Educational services

87 Engineering and management services

95 Admin-Environ Quality, Housing Total

Table 2, continued

$\begin{array}{cccccc}4 & 0 & 0 & 4 & 0 \% & 0 \% \\ 7 & 1 & 1 & 6 & 14 \% & 14 \% \\ 11 & 3 & 3 & 8 & 27 \% & 27 \% \\ 32 & 12 & 6 & 20 & 38 \% & 19 \% \\ 1 & 0 & 0 & 1 & 0 \% & 0 \% \\ 1 & 1 & 0 & 0 & 100 \% & 0 \% \\ 48 & 16 & 8 & 32 & 33 \% & 17 \% \\ 7 & 4 & 1 & 3 & 57 \% & 14 \% \\ 2 & 2 & 2 & 0 & 100 \% & 100 \% \\ 44 & 18 & 13 & 26 & 41 \% & 30 \% \\ 1 & 0 & 0 & 1 & 0 \% & 0 \% \\ 1 & 1 & 1 & 0 & 100 \% & 100 \% \\ 1 & 1 & 0 & 0 & 100 \% & 0 \% \\ 5 & 0 & 0 & 5 & 0 \% & 0 \% \\ 2 & 2 & 2 & 0 & 100 \% & 100 \% \\ 10 & 3 & 1 & 7 & 30 \% & 10 \% \\ 1 & 0 & 0 & 1 & 0 \% & 0 \% \\ 658 & 232 & 85 & 426 & 35 \% & 13 \%\end{array}$

Number and percent of firms by primary two-digit SIC code. Family firms are defined as the sum of all the four subgroups of firms: (1) founder firms; (2) heir firms; (3) family-owned firms; and (4) Leader/owner firms. Founder firms are firms where the founder/founders of the firm holds/hold a position as a board member, or CEO, or a blockholder (at least 5 percent share holding). Heir firms are firms where the heir/heirs (by blood or by marriage) of the founder/founders of the firm holds/hold a position either as a board member, or CEO, or a blockholder (at least 5 percent share holding). Family-owned firms are firms where one individual or several members from the same family together hold more than 10 percent of outstanding shares either directly or indirectly through another family firm or fund which the individual or the family controls or owns. Leader/owner firms are firms where the CEO or a board member is simultaneously a significant shareholder with an outstanding ownership stake of at least 5 percent. The sample comprises 658 firms from S\&P 500 (US), FTE100 (UK), DAX 30 (Germany), CAC 40 (France) and FTSE MIB 40 (Italy) in the 2011 index company lists. 
Table 3 Descriptive statistics of family firms, founder firms and non-family firms in 2008

\begin{tabular}{|c|c|c|c|c|c|c|c|c|c|c|c|c|c|}
\hline \multirow[b]{3}{*}{ Size } & \multicolumn{3}{|c|}{ Non-family firms (I) } & \multicolumn{3}{|c|}{ All family firms (II) } & \multicolumn{3}{|c|}{ Founder firms (III) } & \multicolumn{4}{|c|}{ Difference in Mean } \\
\hline & Obs & Mean & Std.Dev. & Obs & Mean & Std. Dev. & Obs & Mean & Std. Dev. & (I)-(I & & (I)-(II & \\
\hline & 428 & 9.602 & 1.535 & 230 & 9.206 & 1.321 & 85 & 8.931 & 1.356 & 0.396 & $* * *$ & 0.671 & $* * *$ \\
\hline Capital Structure & 428 & 3.837 & 6.051 & 230 & 2.469 & 3.888 & 85 & 1.729 & 2.415 & 1.368 & $* * *$ & 2.108 & $* * *$ \\
\hline Investment & 391 & 0.125 & 0.079 & 213 & 0.155 & 0.109 & 79 & 0.181 & 0.121 & -0.030 & $* * *$ & -0.056 & $* * *$ \\
\hline Ln employee & 420 & 3.064 & 1.421 & 223 & 2.945 & 1.579 & 84 & 2.434 & 1.515 & 0.119 & & 0.630 & $* * *$ \\
\hline ROA & 351 & 0.054 & 0.080 & 154 & 0.045 & 0.102 & 74 & 0.052 & 0.107 & 0.009 & & 0.001 & \\
\hline OROA & 425 & 0.110 & 0.080 & 229 & 0.110 & 0.082 & 85 & 0.110 & 0.094 & 0.000 & & -0.001 & \\
\hline Tobin's Q & 419 & 1.632 & 1.000 & 222 & 1.713 & 1.088 & 83 & 1.886 & 1.238 & -0.081 & & -0.254 & $* *$ \\
\hline Working capital growth & 371 & -0.291 & 2.530 & 205 & -0.029 & 1.697 & 73 & -0.072 & 1.026 & -0.263 & & -0.219 & \\
\hline Short debt change & 426 & -0.070 & 1.993 & 229 & 0.015 & 1.181 & 85 & -0.058 & 1.121 & -0.085 & & -0.012 & \\
\hline Advertising & 427 & 0.008 & 0.019 & 230 & 0.014 & 0.029 & 85 & 0.017 & 0.031 & -0.006 & $* * *$ & -0.010 & $* * *$ \\
\hline Research & 427 & 0.028 & 0.056 & 230 & 0.030 & 0.061 & 85 & 0.045 & 0.076 & -0.002 & & -0.017 & $* *$ \\
\hline Firm age & 428 & 53.439 & 46.681 & 230 & 48.717 & 44.366 & 85 & 28.988 & 19.894 & 4.722 & & 24.451 & $* * *$ \\
\hline Return volatility & 418 & 0.098 & 0.065 & 221 & 0.103 & 0.037 & 82 & 0.112 & 0.032 & -0.005 & & -0.014 & $*$ \\
\hline Ln cash & 418 & 6.498 & 1.601 & 226 & 6.393 & 1.511 & 83 & 6.440 & 1.466 & 0.105 & & 0.058 & \\
\hline Sales/asset & 428 & 0.862 & 0.702 & 230 & 0.895 & 0.634 & 85 & 0.880 & 0.704 & -0.033 & & -0.018 & \\
\hline Expense/asset & 346 & 0.170 & 0.154 & 204 & 0.194 & 0.172 & 72 & 0.232 & 0.174 & -0.025 & $*$ & -0.062 & $* * *$ \\
\hline Cost/asset & 428 & 0.570 & 0.600 & 230 & 0.563 & 0.536 & 85 & 0.527 & 0.580 & 0.007 & & 0.043 & \\
\hline Depreciation/asset & 414 & 0.035 & 0.022 & 221 & 0.037 & 0.022 & 80 & 0.042 & 0.028 & -0.002 & & -0.007 & $* *$ \\
\hline
\end{tabular}

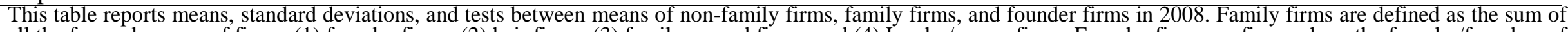

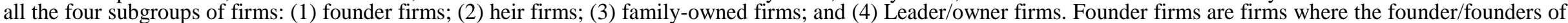

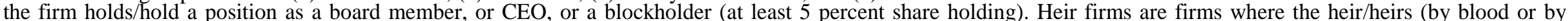

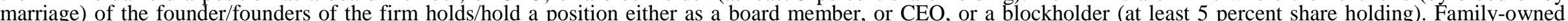

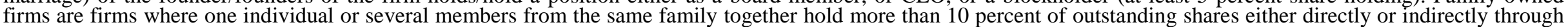

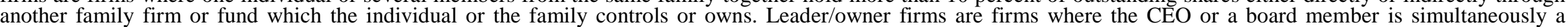

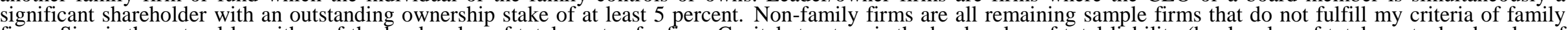

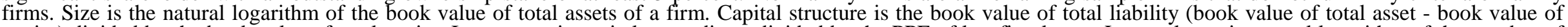

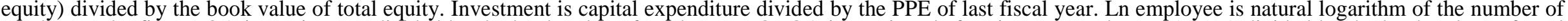

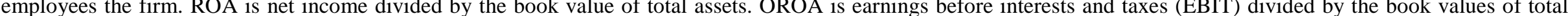

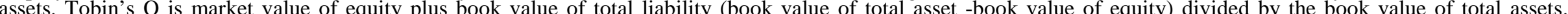

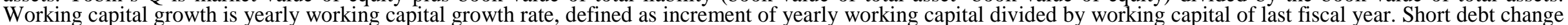

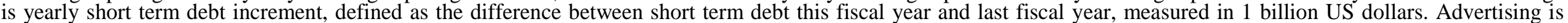

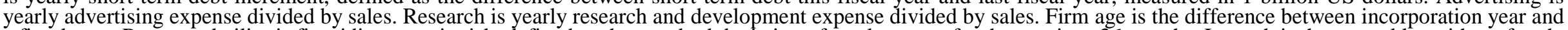

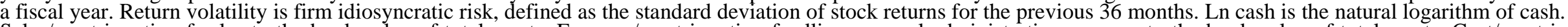

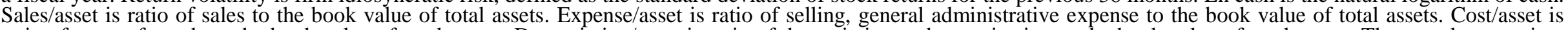

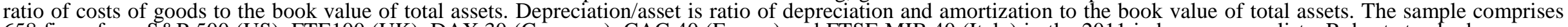

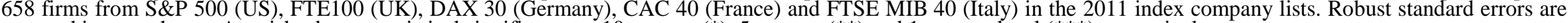
reported in parentheses. Asterisks denote statistical significance at 10 percent (*), 5 percent $(* *)$ and 1 percent level (***) respectively. 
Table 4 Performance before and during the crisis of family firms, founder firms and non-family firms

\begin{tabular}{|c|c|c|c|c|c|c|c|c|c|c|c|c|c|c|c|c|}
\hline & \multicolumn{4}{|c|}{ Non-family firms (I) } & \multicolumn{4}{|c|}{ All family firms (II) } & \multicolumn{4}{|c|}{ Founder firms (III) } & \multicolumn{4}{|c|}{ Difference in Mean } \\
\hline & & & & Std. & & & & Std. & & & & Std. & & & & \\
\hline & Obs & Mean & & Dev. & Obs & Mean & & Dev. & Obs & Mean & & Dev. & (I)-(II) & & (I)-(III) & \\
\hline $\begin{array}{l}\text { OROA } \\
\text { (before crisis, 2006-2008) }\end{array}$ & 425 & 0.111 & & 0.074 & 229 & 0.113 & & 0.072 & 85 & 0.116 & & 0.081 & -0.002 & & -0.005 & \\
\hline $\begin{array}{l}\text { OROA } \\
\text { (during crisis, 2009-2010) }\end{array}$ & 425 & 0.096 & & 0.072 & 229 & 0.100 & & 0.072 & 85 & 0.111 & & 0.087 & -0.004 & & -0.015 & $*$ \\
\hline $\begin{array}{l}\text { Difference in OROA } \\
\text { (during-before) }\end{array}$ & 425 & -0.016 & $* * *$ & 0.046 & 229 & -0.014 & $* * *$ & 0.050 & 85 & -0.005 & & 0.055 & -0.002 & & -0.010 & $*$ \\
\hline $\begin{array}{l}\text { Tobin's Q } \\
\text { (before crisis, 2006-2007) }\end{array}$ & 413 & 2.205 & & 1.321 & 221 & 2.438 & & 1.465 & 83 & 2.811 & & 1.749 & -0.233 & $* *$ & -0.607 & $* * *$ \\
\hline $\begin{array}{l}\text { Tobin's Q } \\
\text { (during crisis, 2008-2010) }\end{array}$ & 413 & 1.756 & & 1.016 & 221 & 1.896 & & 1.106 & 83 & 2.148 & & 1.290 & -0.125 & & -0.380 & $* * *$ \\
\hline $\begin{array}{l}\text { Difference in Tobin's Q } \\
\text { (during -before) }\end{array}$ & 413 & -0.449 & $* * *$ & 0.681 & 221 & -0.541 & $* * *$ & 0.764 & 83 & -0.664 & $* * *$ & 1.038 & 0.093 & & 0.215 & $* *$ \\
\hline
\end{tabular}

This table reports the means, standard deviations and tests between means of performance before and during the financial crisis of family firms, founder firms and non-family firms from 2006 through 2010. Family firms are defined as the sum of all the four subgroups of firms: (1) founder firms; (2) heir firms; (3) family-owned firms; and (4) Leader/owner firms. Founder firms are firms where the founder/founders of the firm holds/hold a position as a board member, or CEO, or a blockholder (at least 5 percent share holding). Heir firms are firms where the heir/heirs (by blood or by marriage) of the founder/founders of the firm holds/hold a position either as a board member, or CEO, or a blockholder (at least 5 percent share holding). Family-owned firms are firms where one individual or several members from the same family together hold more than 10 percent of outstanding shares either directly or indirectly through another family firm or fund which the individual or the family controls or owns. Leader/owner firms are firms where the CEO or a board member is simultaneously a significant shareholder with an outstanding ownership stake of at least 5 percent. Non-family firms are all remaining sample firms that do not fulfill my criteria of family firms. OROA is earnings before interests and taxes (EBIT) divided by the book values of total assets. Tobin's Q is market value of equity plus book value of total liability (book value of total asset -book value of equity) divided by the book value of total assets. The sample comprises 658 firms from S\&P 500 (US), FTE100 (UK), DAX 30 (Germany), CAC 40 (France) and FTSE MIB 40 (Italy) in the 2011 index company lists. Robust standard errors are reported in parentheses. Asterisks denote statistical significance at 10 percent $(*), 5$ percent $\left({ }^{* *}\right)$ and 1 percent level $(* * *)$ respectively. 
Table 5 Performance of family firms vs. non-family firms during the financial crisis

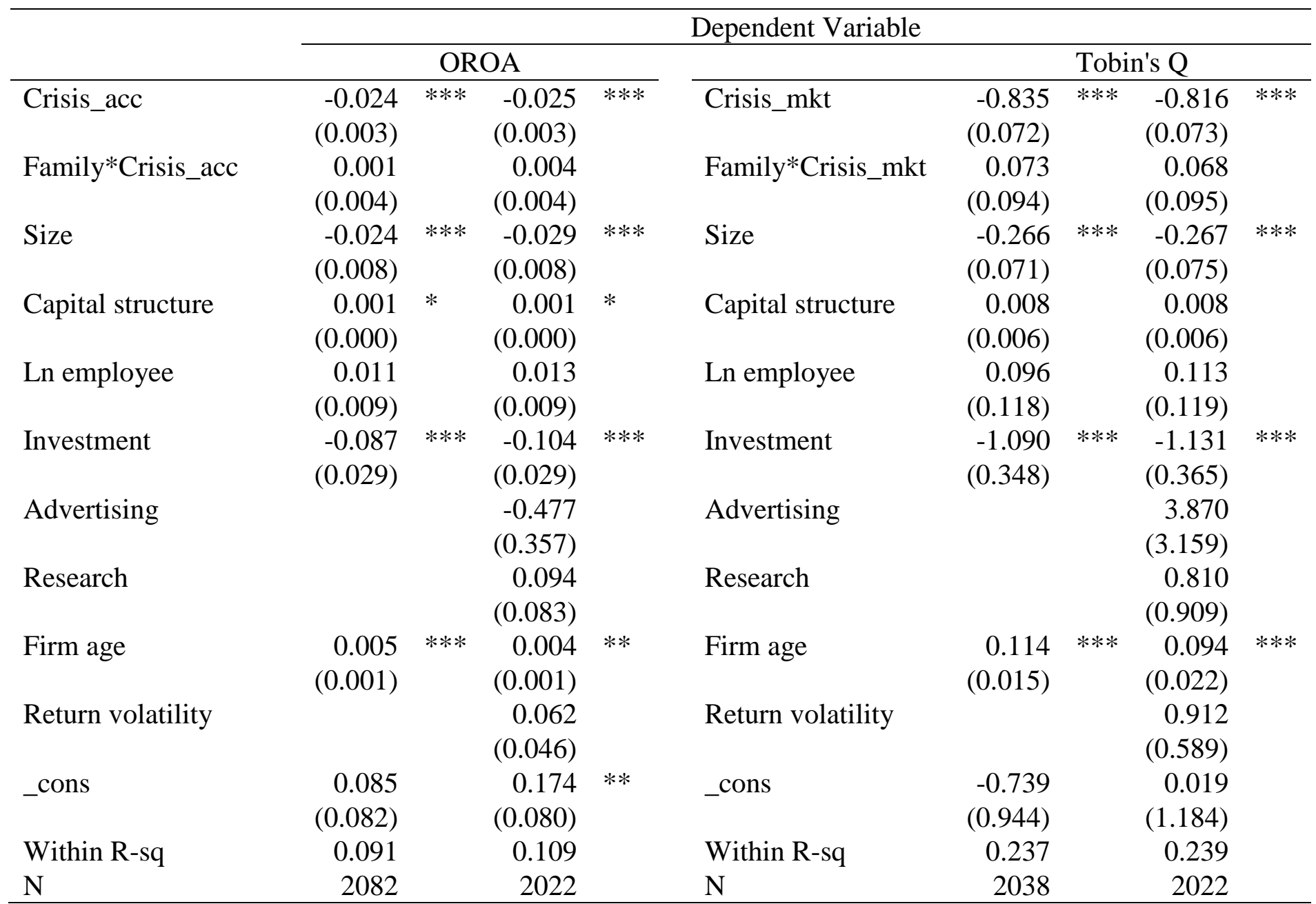

This table reports results of firm fixed effect model regression of firm performance before and during the financial crisis from 2006 through 2010. Family* Crisis_acc is an interaction between variable Family and Crisis_acc. Crisis_acc is a dummy which is one if the fiscal year is 2009 and 2010. This variable indicates the years when financial crisis significantly strikes real economy. Family*Crisis_mkt is an interaction between variable Family and Crisis_mkt. Crisis_mkt is a dummy which is one if fiscal year is 2008, 2009 and 2010. This variable indicates the years when financial crisis significantly strikes the financial market. Family is a dummy variable, which is one if the sample firm is a family firm. Family firms are the sum of all the four subgroups of firms: (1) founder firms; (2) heir firms; (3) family-owned firms; and (4) Leader/owner firms. Founder firms are firms where the founder/founders of the firm holds/hold a position as a board member, or CEO, or a blockholder (at least 5 percent share holding). Heir firms are firms where the heir/heirs (by blood or by marriage) of the founder/founders of the firm holds/hold a position either as a board member, or CEO, or a blockholder (at least 5 percent share holding). Family-owned firms are firms where one individual or several members from the same family together hold more than 10 percent of outstanding shares either directly or indirectly through another family firm or fund which the individual or the family controls or owns. Leader/owner firms are firms where the CEO or a board member is simultaneously a significant shareholder with an outstanding ownership stake of at least 5 percent. OROA is earnings before interests and taxes (EBIT) divided by the book values of total assets. Tobin's Q is market value of equity plus book value of total liability (book value of total asset -book value of equity) divided by the book value of total assets. Size is the natural logarithm of the book value of total assets of a firm. Capital structure is the book value of total liability (book value of total asset - book value of equity) divided by the book value of total equity. Investment is capital expenditure divided by the PPE of last fiscal year. Ln employee is natural logarithm of the number of employees the firm. Advertising is yearly advertising expense divided by sales. Research is yearly research and development expense divided by sales. Firm age is the difference between incorporation year and a fiscal year. Return volatility is firm idiosyncratic risk, defined as the standard deviation of stock returns for the previous 36 months. The sample comprises 658 firms from S\&P 500 (US), FTE100 (UK), DAX 30 (Germany), CAC 40 (France) and FTSE MIB 40 (Italy) in the 2011 index company lists. Robust standard errors are reported in parentheses. Asterisks denote statistical significance at 10 percent $(*), 5$ percent $(* *)$ and 1 percent level $(* * *)$ respectively. 
Table 6 Fixed effect estimation of founder firms outperformance in OROA during the crisis

\begin{tabular}{|c|c|c|c|c|c|c|c|c|c|}
\hline \multirow{4}{*}{ Crisis_acc } & \multicolumn{9}{|c|}{ Dependent Variable } \\
\hline & \multicolumn{4}{|c|}{ OROA } & \multirow{3}{*}{ Crisis_mkt } & \multicolumn{4}{|c|}{ Tobin's Q } \\
\hline & -0.024 & $* * *$ & -0.025 & $* * *$ & & -0.806 & $* * *$ & -0.785 & $* * *$ \\
\hline & $(0.003)$ & & $(0.003)$ & & & $(0.069)$ & & $(0.070)$ & \\
\hline \multirow[t]{2}{*}{ Founder*Crisis_acc } & 0.017 & $* *$ & 0.017 & $* *$ & Founder*Crisis_mkt & 0.023 & & 0.004 & \\
\hline & $(0.008)$ & & $(0.008)$ & & & $(0.166)$ & & $(0.171)$ & \\
\hline \multirow[t]{2}{*}{ Heir*Crisis_acc } & 0.001 & & 0.001 & & Heir*Crisis_mkt & 0.167 & & 0.182 & \\
\hline & $(0.006)$ & & $(0.006)$ & & & $(0.130)$ & & $(0.131)$ & \\
\hline \multirow[t]{2}{*}{ Family_owned*Crisis_acc } & -0.002 & & 0.002 & & Family_owned*Crisis_mkt & -0.048 & & -0.057 & \\
\hline & $(0.007)$ & & $(0.007)$ & & & $(0.110)$ & & $(0.112)$ & \\
\hline \multirow[t]{2}{*}{ Leader_owner*Crisis_acc } & -0.008 & & -0.010 & & Leader_owner*Crisis_mkt & -0.018 & & -0.021 & \\
\hline & $(0.007)$ & & $(0.008)$ & & & $(0.127)$ & & $(0.127)$ & \\
\hline \multirow[t]{2}{*}{ Size } & -0.026 & $* * *$ & -0.030 & $* * *$ & Size & -0.267 & $* * *$ & -0.267 & $* * *$ \\
\hline & $(0.008)$ & & $(0.008)$ & & & $(0.073)$ & & $(0.077)$ & \\
\hline \multirow[t]{2}{*}{ Capital structure } & 0.001 & & 0.001 & & Capital structure & 0.008 & & 0.008 & \\
\hline & $(0.000)$ & & $(0.000)$ & & & $(0.006)$ & & $(0.006)$ & \\
\hline \multirow[t]{2}{*}{ Ln employee } & 0.011 & & 0.014 & & Ln employee & 0.101 & & 0.118 & \\
\hline & $(0.009)$ & & $(0.009)$ & & & $(0.118)$ & & $(0.120)$ & \\
\hline \multirow[t]{2}{*}{ Investment } & -0.081 & $* * *$ & -0.098 & $* * *$ & Investment & -1.065 & $* * *$ & -1.122 & $* * *$ \\
\hline & $(0.027)$ & & $(0.027)$ & & & $(0.350)$ & & $(0.368)$ & \\
\hline \multirow[t]{2}{*}{ Advertising } & & & -0.499 & & Advertising & & & 3.855 & \\
\hline & & & $(0.355)$ & & & & & (3.154) & \\
\hline \multirow[t]{2}{*}{ Research } & & & 0.110 & & Research & & & 0.837 & \\
\hline & & & $(0.082)$ & & & & & $(0.917)$ & \\
\hline \multirow[t]{2}{*}{ Firm age } & 0.005 & $* * *$ & 0.004 & $* * *$ & Firm age & 0.114 & $* * *$ & 0.094 & $* * *$ \\
\hline & 0.0015 & & 0.00144 & & & 0.0148 & & 0.02265 & \\
\hline \multirow[t]{2}{*}{ Return volatility } & & & 0.063 & & Return volatility & & & 0.930 & \\
\hline & & & $(0.046)$ & & & & & $(0.595)$ & \\
\hline \multirow[t]{2}{*}{ _cons } & 0.074 & & 0.165 & $* *$ & _cons & -0.782 & & 0.010 & \\
\hline & $(0.081)$ & & $(0.078)$ & & & $(0.953)$ & & (1.197) & \\
\hline Within R-sq & 0.097 & & 0.114 & & Within R-sq & 0.238 & & 0.240 & \\
\hline $\mathrm{N}$ & 2082 & & 2022 & & $\mathrm{~N}$ & 2038 & & 2022 & \\
\hline \multicolumn{10}{|c|}{ 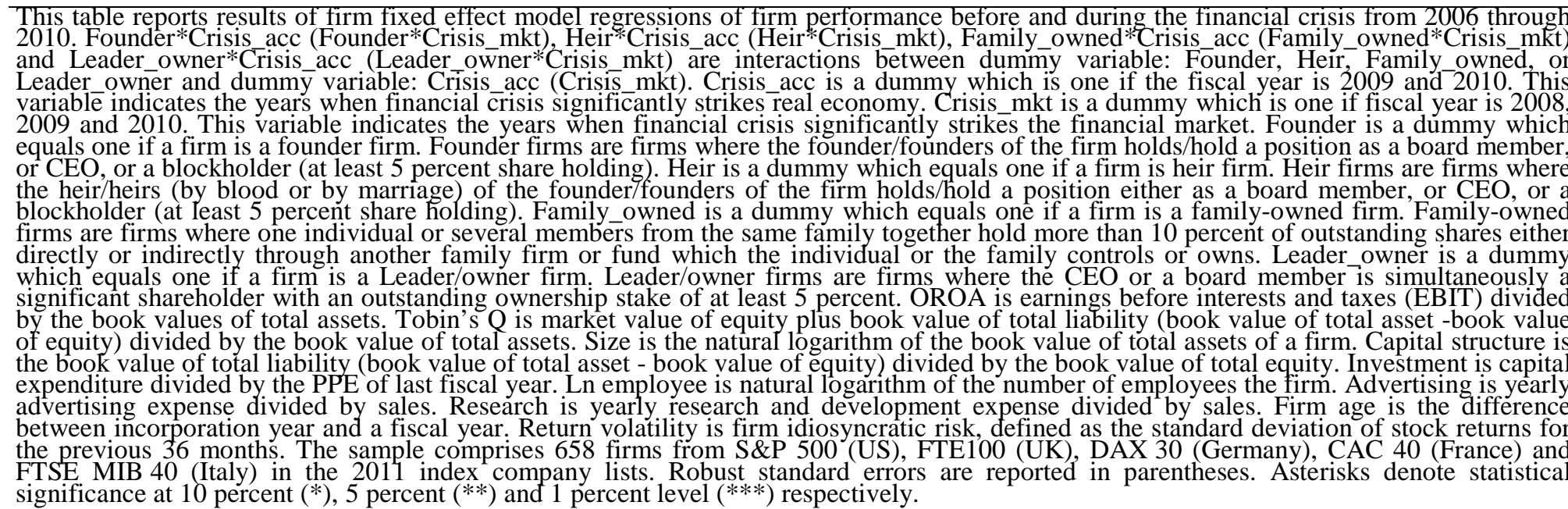 } \\
\hline
\end{tabular}


Table 7 Heckman two step estimation of founder firm outperformance in OROA during the crisis

\begin{tabular}{|c|c|c|c|c|c|}
\hline \multicolumn{3}{|c|}{ First stage regression } & \multicolumn{3}{|c|}{ Treatment regression } \\
\hline \multicolumn{3}{|c|}{$\begin{array}{c}\text { Dependent variable: } \\
\text { Founder }\end{array}$} & \multicolumn{3}{|c|}{$\begin{array}{l}\text { Dependent variable: } \\
\text { Difference in OROA }\end{array}$} \\
\hline Old firm & $\begin{array}{r}-0.885 \\
(0.186)\end{array}$ & $* * *$ & Founder & $\begin{array}{r}0.047 \\
(0.022)\end{array}$ & $* *$ \\
\hline US & $\begin{array}{r}0.332 \\
(0.193)\end{array}$ & $*$ & Heir & $\begin{array}{r}-0.001 \\
(0.007)\end{array}$ & \\
\hline Sales growth rate & $\begin{array}{r}-0.606 \\
(0.381)\end{array}$ & & Family_owned & $\begin{array}{r}0.003 \\
(0.006)\end{array}$ & \\
\hline Ln cash & $\begin{array}{r}0.177 \\
(0.074)\end{array}$ & $* *$ & Leader_owner & $\begin{array}{r}-0.004 \\
(0.007)\end{array}$ & \\
\hline Size & $\begin{array}{r}-0.112 \\
(0.089)\end{array}$ & & Size & $\begin{array}{r}-0.005 \\
(0.002)\end{array}$ & $* *$ \\
\hline Capital structure & $\begin{array}{r}-0.031 \\
(0.024)\end{array}$ & & Capital structure & $\begin{array}{r}0.002 \\
(0.001)\end{array}$ & $* * *$ \\
\hline Ln employee & $\begin{array}{r}-0.137 \\
(0.068)\end{array}$ & $* *$ & Ln employee & $\begin{array}{r}0.002 \\
(0.002)\end{array}$ & \\
\hline Investment & $\begin{array}{r}1.762 \\
(0.803)\end{array}$ & $* *$ & Investment & $\begin{array}{r}-0.074 \\
(0.027)\end{array}$ & $* * *$ \\
\hline Advertising & $\begin{array}{r}5.030 \\
(2.678)\end{array}$ & $*$ & Advertising & $\begin{array}{r}0.322 \\
(0.092)\end{array}$ & $* * *$ \\
\hline Research & $\begin{array}{r}-1.226 \\
(1.200)\end{array}$ & & Research & $\begin{array}{r}0.108 \\
(0.037)\end{array}$ & $* * *$ \\
\hline Return volatility & $\begin{array}{r}0.825 \\
(1.113)\end{array}$ & & Return volatility & $\begin{array}{r}-0.130 \\
(0.036)\end{array}$ & $* * *$ \\
\hline _cons & $\begin{array}{r}-1.058 \\
(0.637)\end{array}$ & $*$ & _cons & $\begin{array}{r}0.025 \\
(0.017)\end{array}$ & \\
\hline & & & Heckman's lambda & $\begin{array}{r}-0.020 \\
(0.012)\end{array}$ & $*$ \\
\hline Pseudo R-sq & 0.166 & & Wald & 97 & \\
\hline $\mathrm{N}$ & 567 & & $\mathrm{~N}$ & 567 & \\
\hline
\end{tabular}

This table reports results of Heckman two step regression of firm performance before and during the financial crisis on founder dummy. Founder is a dummy which equals one if a firm is a founder firm. Founder firms are firms where the founder/founders of the firm holds/hold a position as a board member, or CEO, or a blockholder (at least 5 percent share holding). Heir is a dummy which equals one if a firm is heir firm. Heir firms are firms where the heir/heirs (by blood or by marriage) of the founder/founders of the firm holds/hold a position either as a board member, or CEO, or a blockholder (at least 5 percent share holding). Family owned is a dummy which equals one if a firm is a family-owned firm. Family-owned firms are firms where one individual or several members from the same family together hold more than 10 percent of outstanding shares either directly or indirectly through another family firm or fund which the individual or the family controls or owns. Leader owner is a dummy which equals one if a firm is a Leader/owner firm. Leader/owner firms are firms where the CEO or a board member is simultaneously a significant shareholder with an outstanding ownership stake of at least 5 percent. Difference in OROA is the difference between average OROA of the period 2009-2010 and average OROA of the period 20062008.OROA is earnings before interests and taxes (EBIT) divided by the book values of total assets. Old firm is a dummy variable, which is one if the sample firm is incorporated before 1960. US is a dummy variable, which is one if the headquarter of a sample firm is in the US. Sale growth rate is yearly sales growth rate, defined as increment of yearly total sales divided by total sales of last fiscal year Size is the natural logarithm of the book value of total assets of a firm. Capital structure is the book value of total liability (book value of total asset - book value of equity) divided by the book value of total equity. Investment is capital expenditure divided by the PPE of last fiscal year. Ln employee is natural logarithm of the number of employees the firm. Advertising is yearly advertising expense divided by sales. Research is yearly research and development expense divided by sales. Return volatility is firm idiosyncratic risk, defined as the standard deviation of stock returns for the previous 36 months. The sample comprises 658 firms from S\&P 500 (US), FTE100 (UK), DAX 30 (Germany), CAC 40 (France) and FTSE MIB 40 (Italy) in the 2011 index company lists. Robust standard errors are reported in parentheses. Asterisks denote statistical significance at 10 percent $(*), 5$ percent $(* *)$ and 1 percent level $(* * *)$ respectively. 
Table 8 Monthly average return volatility of the sample firms

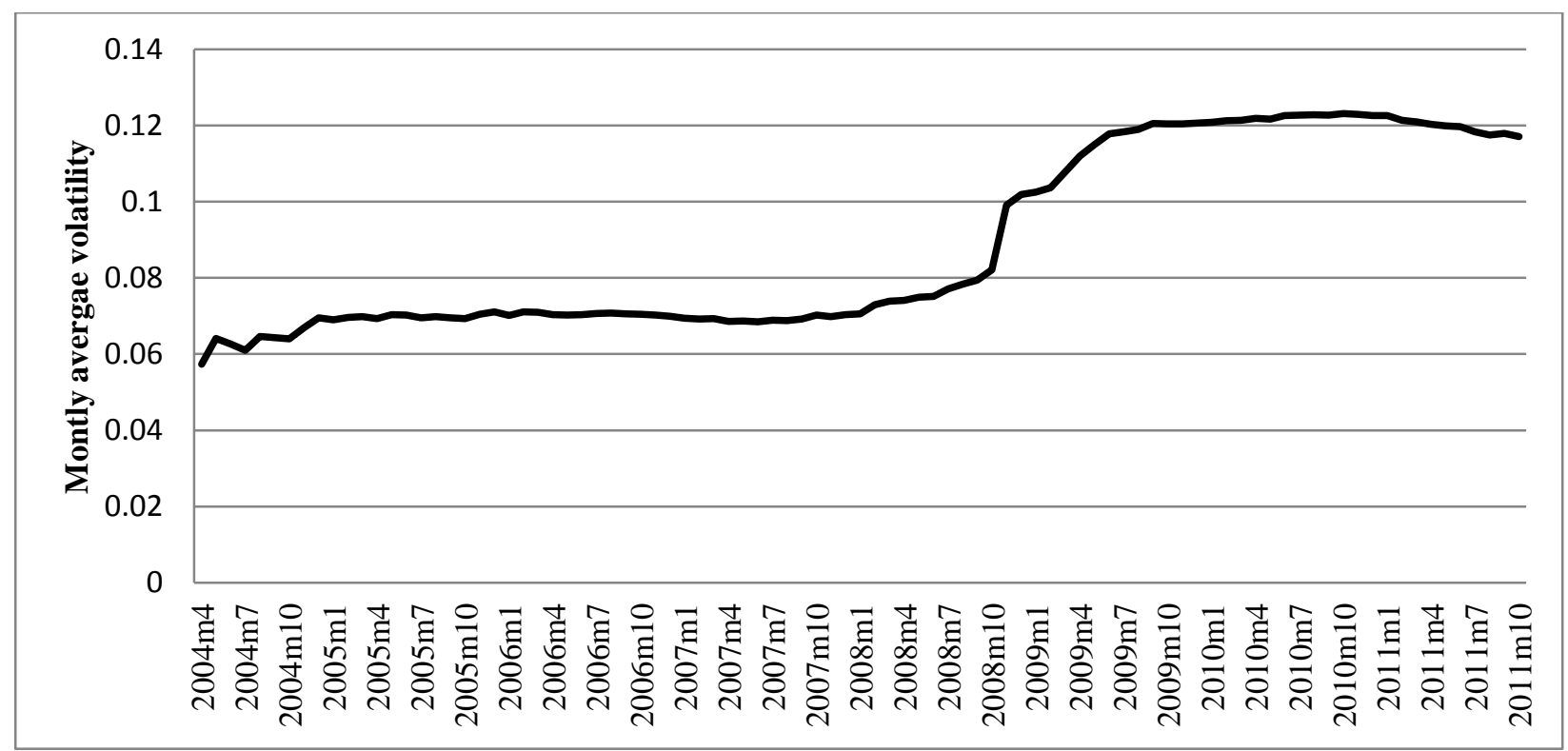

This table shows the average monthly return volatility of the sample. Return volatility is firm idiosyncratic risk, defined as the standard deviation of stock returns for the previous 36 months. Source: Datastream. 
Table 9 Founder firm OROA premium investigations

\begin{tabular}{|c|c|c|c|c|c|c|c|c|}
\hline \multirow{4}{*}{ Crisis_acc } & \multicolumn{8}{|c|}{ Dependent Variable } \\
\hline & \multicolumn{2}{|c|}{ Sales/asset } & \multicolumn{2}{|c|}{ Cost/asset } & \multicolumn{2}{|c|}{ Expense/asset } & \multicolumn{2}{|c|}{ Depreciation/asset } \\
\hline & -0.118 & $* * *$ & -0.085 & $* * *$ & -0.015 & $* * *$ & 0.000 & \\
\hline & $(0.013)$ & & $(0.010)$ & & $(0.003)$ & & $(0.001)$ & \\
\hline \multirow[t]{2}{*}{ Founder*Crisis_acc } & 0.015 & & -0.004 & & -0.011 & $* *$ & -0.003 & $*$ \\
\hline & $(0.021)$ & & $(0.018)$ & & $(0.005)$ & & $(0.002)$ & \\
\hline \multirow[t]{2}{*}{ Heir*Crisis_acc } & -0.004 & & 0.005 & & 0.001 & & -0.001 & \\
\hline & $(0.021)$ & & $(0.016)$ & & $(0.005)$ & & $(0.001)$ & \\
\hline \multirow[t]{2}{*}{ Family_owned*Crisis_acc } & 0.025 & & 0.015 & & 0.003 & & 0.001 & \\
\hline & $(0.024)$ & & $(0.018)$ & & $(0.004)$ & & $(0.001)$ & \\
\hline \multirow[t]{2}{*}{ Leader_owner*Crisis_acc } & -0.026 & & -0.012 & & -0.001 & & 0.002 & \\
\hline & $(0.022)$ & & $(0.018)$ & & $(0.005)$ & & $(0.001)$ & \\
\hline \multirow[t]{2}{*}{ Size } & -0.059 & & -0.025 & & -0.011 & & 0.006 & $* *$ \\
\hline & $(0.039)$ & & $(0.034)$ & & $(0.005)$ & & $(0.002)$ & \\
\hline \multirow[t]{2}{*}{ Capital structure } & 0.002 & & 0.000 & & 0.001 & & 0.000 & \\
\hline & $(0.001)$ & & $(0.001)$ & & $(0.001)$ & & $(0.000)$ & \\
\hline \multirow[t]{2}{*}{ Ln employee } & 0.091 & $* * *$ & 0.050 & $* *$ & 0.024 & $* * *$ & 0.001 & \\
\hline & $(0.030)$ & & $(0.022)$ & & $(0.006)$ & & $(0.002)$ & \\
\hline \multirow[t]{2}{*}{ Investment } & -0.012 & & 0.134 & & 0.027 & & 0.003 & \\
\hline & $(0.120)$ & & $(0.103)$ & & $(0.019)$ & & $(0.006)$ & \\
\hline \multirow[t]{2}{*}{ Advertising } & -1.330 & & -0.977 & & 0.014 & & 0.238 & $*$ \\
\hline & (1.691) & & (1.120) & & $(0.428)$ & & $(0.136)$ & \\
\hline \multirow[t]{2}{*}{ Research } & 0.135 & & -0.366 & & -0.021 & & 0.019 & \\
\hline & $(0.278)$ & & (0.396) & & $(0.063)$ & & $(0.019)$ & \\
\hline \multirow[t]{2}{*}{ Firm age } & 0.013 & $* *$ & 0.016 & $* * *$ & 0.000 & & -0.001 & $* *$ \\
\hline & $(0.006)$ & & $(0.005)$ & & $(0.001)$ & & $(0.000)$ & \\
\hline \multirow[t]{2}{*}{ Return volatility } & 0.131 & & -0.044 & & 0.149 & $* * *$ & 0.001 & \\
\hline & $(0.161)$ & & $(0.135)$ & & $(0.045)$ & & $(0.012)$ & \\
\hline \multirow[t]{2}{*}{ _cons } & 0.552 & * & -0.124 & & 0.205 & $* *$ & 0.024 & \\
\hline & $(0.282)$ & & $(0.245)$ & & $(0.079)$ & & $(0.020)$ & \\
\hline Within R-sq & 0.144 & & 0.107 & & 0.095 & & 0.065 & \\
\hline $\mathrm{N}$ & 2022 & & 2022 & & 1765 & & 2019 & \\
\hline
\end{tabular}

This table reports results of firm fixed effect model regressions of firm accounting performance before and during the financial crisis from 2006 through 2010. Founder*Crisis_acc, Heir*Crisis_acc, Family_owned*Crisis_acc and Leader_owner *Crisis_acc are interactions between dummy variable: Founder, Heir, Family_owned, or Leader_owner and dummy variable: Crisis_acc. Crisis_acc is a dummy which is one if the fiscal year is 2009 and 2010 . This variable indicates the years when financial crisis significantly strikes real economy. Founder is a dummy which equals one if a firm is a founder firm. Founder firms are firms where the founder/founders of the firm holds/hold a position as a board member, or CEO, or a blockholder (at least 5 percent share holding). Heir is a dummy which equals one if a firm is heir firm. Heir firms are firms where the heir/heirs (by blood or by marriage) of the founder/founders of the firm holds/hold a position either as a board member, or CEO, or a blockholder (at least 5 percent share holding). Family_owned is a dummy which equals one if a firm is a familyowned firm. Family-owned firms are firms where one individual or several members from the same family together hold more than 10 percent of outstanding shares either directly or indirectly through another family firm or fund which the individual or the family controls or owns. Leader_owner is a dummy which equals one if a firm is a Leader/owner firm. Leader/owner firms are firms where the CEO or a board member is simultaneously a significant shareholder with an outstanding ownership stake of at least 5 percent. Sales/asset is ratio of sales to the book value of total assets. Expense/asset is ratio of selling, general administrative expense to the book value of total assets. Cost/asset is ratio of costs of goods to the book value of total assets. Depreciation/asset is ratio of depreciation and amortization to the book value of total assets. Size is the natural logarithm of the book value of total assets of a firm. Capital structure is the book value of total liability (book value of total asset - book value of equity) divided by the book value of total equity. Investment is capital expenditure divided by the PPE of last fiscal year. Ln employee is natural logarithm of the number of employees the firm. Advertising is yearly advertising expense divided by sales. Research is yearly research and development expense divided by sales. Firm age is the difference between incorporation year and a fiscal year. Return volatility is firm idiosyncratic risk, defined as the standard deviation of stock returns for the previous 36 months. The sample comprises 658 firms from S\&P 500 (US), FTE100 (UK), DAX 30 (Germany), CAC 40 (France) and FTSE MIB 40 (Italy) in the 2011 index company lists. Robust standard errors are reported in parentheses. Asterisks denote statistical significance at 10 percent $(*), 5$ percent $(* *)$ and 1 percent level $(* * *)$ respectively. 
Table 10 Finance and investment strategy of founder firms during crisis

\begin{tabular}{|c|c|c|c|c|c|c|}
\hline \multirow{3}{*}{ Crisis_acc } & \multicolumn{6}{|c|}{ Dependent variable } \\
\hline & \multicolumn{2}{|c|}{ Investment } & \multicolumn{2}{|c|}{ Short debt change } & \multicolumn{2}{|c|}{ Capital structure } \\
\hline & $\begin{array}{l}-0.018 \\
(0.004)\end{array}$ & $* * *$ & $\begin{array}{r}-0.184 \\
(0.139)\end{array}$ & & $\begin{array}{r}-0.124 \\
(0.199)\end{array}$ & \\
\hline Founder*Crisis_acc & $\begin{array}{r}-0.021 \\
(0.010)\end{array}$ & $* *$ & $\begin{array}{r}0.431 \\
(0.184)\end{array}$ & $* *$ & $\begin{array}{r}0.807 \\
(0.447)\end{array}$ & $*$ \\
\hline Heir*Crisis_acc & $\begin{array}{l}-0.006 \\
(0.008)\end{array}$ & & $\begin{array}{r}0.231 \\
(0.145)\end{array}$ & & $\begin{array}{l}-0.101 \\
(0.389)\end{array}$ & \\
\hline Family_owned*Crisis_acc & $\begin{array}{r}0.013 \\
(0.007)\end{array}$ & $*$ & $\begin{array}{r}-0.077 \\
(0.160)\end{array}$ & & $\begin{array}{r}-0.039 \\
(0.211)\end{array}$ & \\
\hline Leader_owner*Crisis_acc & $\begin{array}{r}-0.012 \\
(0.009)\end{array}$ & & $\begin{array}{r}-0.118 \\
(0.195)\end{array}$ & & $\begin{array}{l}-0.609 \\
(0.404)\end{array}$ & \\
\hline Size & $\begin{array}{r}0.003 \\
(0.008)\end{array}$ & & $\begin{array}{r}-0.975 \\
(0.287)\end{array}$ & $* * *$ & $\begin{array}{r}0.550 \\
(0.435)\end{array}$ & \\
\hline Tobin's Q & $\begin{array}{r}0.019 \\
(0.004)\end{array}$ & $* * *$ & $\begin{array}{r}-0.060 \\
(0.046)\end{array}$ & & $\begin{array}{l}-0.121 \\
(0.141)\end{array}$ & \\
\hline Ln cash & $\begin{array}{r}0.001 \\
(0.002)\end{array}$ & & & & & \\
\hline Firm age & $\begin{array}{r}-0.002 \\
(0.002)\end{array}$ & & & & & \\
\hline Profitability & & & $\begin{array}{r}0.004 \\
(0.446)\end{array}$ & & $\begin{array}{r}-1.442 \\
(1.314)\end{array}$ & \\
\hline Tangibility & & & $\begin{array}{r}-0.857 \\
(0.642)\end{array}$ & & $\begin{array}{r}1.752 \\
(1.350)\end{array}$ & \\
\hline Dividend payout & & & $\begin{array}{r}2.202 \\
(1.563)\end{array}$ & & $\begin{array}{r}7.545 \\
(6.291)\end{array}$ & \\
\hline Non-debt tax shield & & & $\begin{array}{r}9.969 \\
(8.592)\end{array}$ & & $\begin{array}{l}16.399 \\
(8.725)\end{array}$ & $*$ \\
\hline Return volatility & & & $\begin{array}{r}-0.855 \\
(3.399)\end{array}$ & & $\begin{array}{l}-9.565 \\
(5.200)\end{array}$ & $*$ \\
\hline _cons & $\begin{array}{r}0.180 \\
(0.087)\end{array}$ & $* *$ & $\begin{array}{r}9.656 \\
(3.186)\end{array}$ & $* * *$ & $\begin{array}{r}-3.144 \\
(4.884)\end{array}$ & \\
\hline Within R-sq & 0.217 & & 0.025 & & 0.023 & \\
\hline $\mathrm{N}$ & 2504 & & 2430 & & 2432 & \\
\hline
\end{tabular}

This table reports results of firm fixed effect model regressions of firm accounting performance before and during the financial crisis from 2006 through 2010. Founder*Crisis_acc, Heir*Crisis_acc, Family_owned*Crisis_acc and Leader_owner*Crisis_acc are interactions between dummy variable: Founder, Heir, Family_owned, or Leader owner and dummy variable: Crisis a the fiscal year is 2009 and 2010. This variable indicates the years when financial crisis significantly strikes real economy. Founder is a dummy which equals one if a firm is a founder firm. Founder firms are firms where the founder/founders of the firm holds/hold a position as a board member, or CEO, or a blockholder (at least 5 percent share holding). Heir is a dummy which equals one if a firm is heir firm. Heir firms are firms where the heir/heirs (by blood or by marriage) of the founder/founders of the firm holds/hold a position either as a board member, or CEO, or a blockholder (at least 5 percent share holding). Family owned is a dummy which equals one if a firm is a familyowned firm. Family-owned firms are firms where one individual or several members from the same family together hold more than 10 percent of outstanding shares either directly or indirectly through another family firm or fund which the individual or the family controls or owns. Leader owner is a dummy which equals one if a firm is a Leader/owner firm. Leader/owner firms are firms where the CEO or a board member is simultaneously a significant shareholder with an outstanding ownership stake of at least 5 percent. Investment is capital expenditure divided by the PPE of last fiscal year. Short debt change is yearly short term debt increment, defined as the difference between short term debt this fiscal year and last fiscal year, measured in 1 billion US dollars. Capital structure is the book value of total liability (book value of total asset - book value of equity) divided by the book value of total equity. Ln cash is the natural logarithm of cash. Size is the natural logarithm of the book value of total assets of a firm. Tobin's Q is market value of equity plus book value of total liability (book value of total asset -book value of equity) divided by the book value of total assets. Firm age is the difference between incorporation year and a fiscal year. Profitability is Operating Return on Assets of last fiscal year. Tangibility is tangible assets divided by the book values of total assets. Dividend payout is dividend divided by sales. Non-debt tax shield is depreciation and amortization divided by the book value of total assets. Return volatility is firm idiosyncratic risk, defined as the standard deviation of stock returns for the previous 36 months. The sample comprises 658 firms from S\&P 500 (US), FTE100 (UK), DAX 30 (Germany), CAC 40 (France) and FTSE MIB 40 (Italy) in the 2011 index company lists. Robust standard errors are reported in parentheses. Asterisks denote statistical significance at 10 percent $(*)$, 5 percent $(* *)$ and 1 percent level $(* * *)$ respectively. 
Appendix 1 S\&P index slumps in September 2008

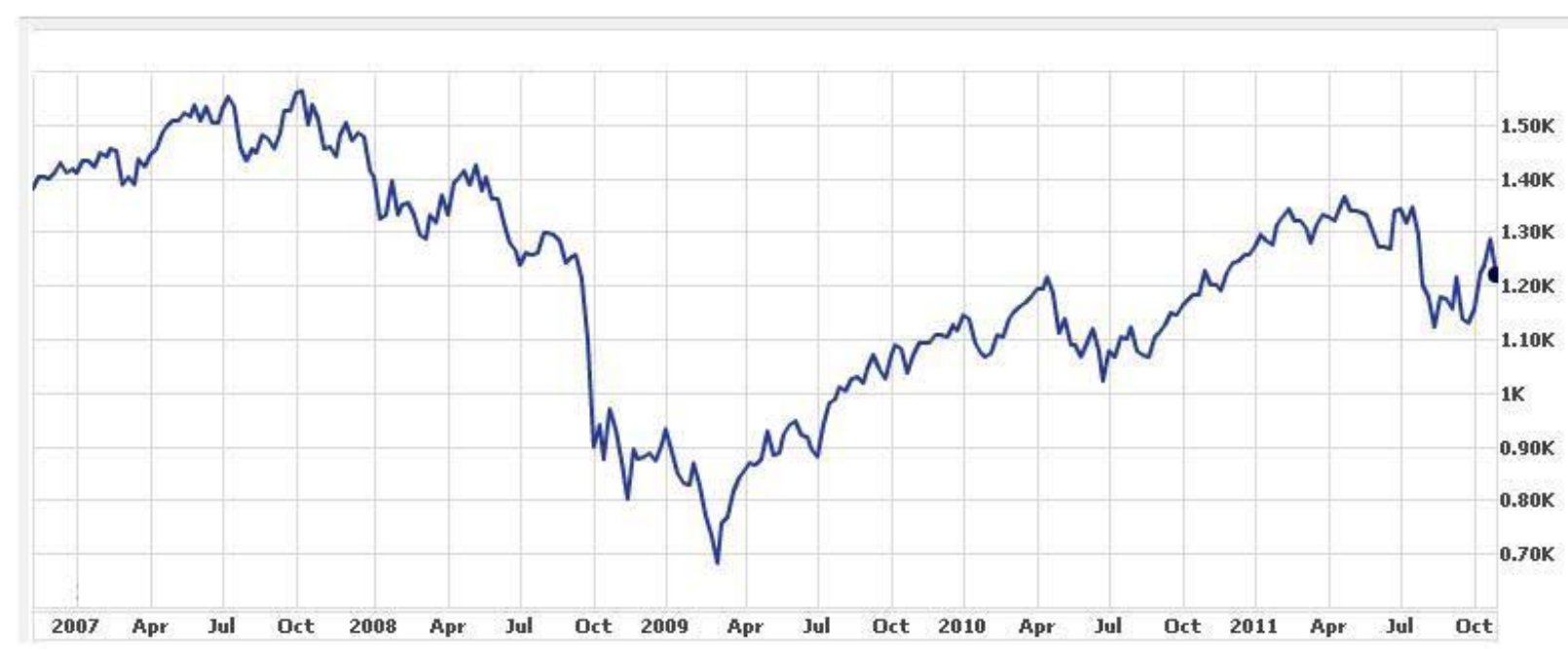

Source: Yahoo finance (finance.yahoo.com)

Appendix 2 GDP annual growth rate for the US, the UK, Germany, France, and Italy

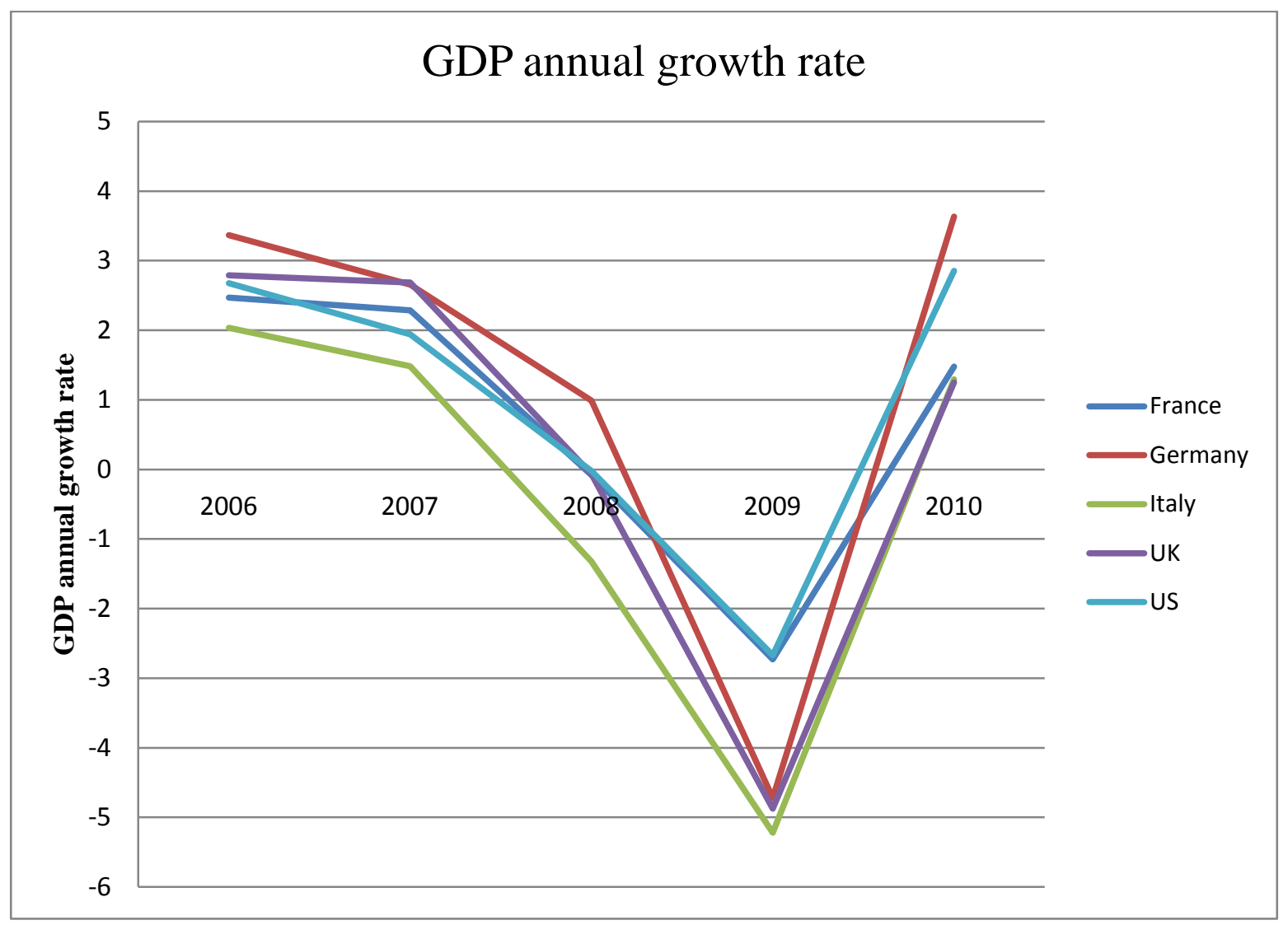

Source: world Bank 
Appendix 3 Descriptive statistics of heir firms, family-owned firms, leader/owner firms and non-family firms in 2008

\begin{tabular}{|c|c|c|c|c|c|c|c|c|c|c|c|c|c|c|c|c|c|c|}
\hline \multirow[b]{3}{*}{ Size } & \multicolumn{3}{|c|}{ Non-family firms (1) } & \multicolumn{3}{|c|}{ Heir firms (2) } & \multicolumn{3}{|c|}{ Family-owned firms (3) } & \multicolumn{3}{|c|}{ Leader/owner firms (4) } & \multicolumn{6}{|c|}{ Difference in Mean } \\
\hline & \multirow{2}{*}{$\begin{array}{r}\text { Obs } \\
428\end{array}$} & \multirow{2}{*}{$\frac{\text { Mean }}{9.602}$} & \multirow{2}{*}{$\begin{array}{r}\text { Std Dev. } \\
1.535\end{array}$} & \multirow{2}{*}{$\begin{array}{r}\text { Obs } \\
74\end{array}$} & \multirow{2}{*}{$\begin{array}{r}\text { Mean } \\
9.308\end{array}$} & \multirow{2}{*}{$\begin{array}{c}\text { Std. Dev. } \\
1.068\end{array}$} & \multirow{2}{*}{$\frac{\text { Obs }}{159}$} & \multirow{2}{*}{$\begin{array}{r}\text { Mean } \\
9.259\end{array}$} & \multirow{2}{*}{$\begin{array}{r}\text { Std.Dev. } \\
1.376\end{array}$} & \multirow{2}{*}{$\frac{\text { Obs }}{132}$} & \multirow{2}{*}{$\frac{\text { Mean }}{9.184}$} & \multirow{2}{*}{$\begin{array}{r}\text { Std.Dev. } \\
1.401\end{array}$} & \multirow{2}{*}{$\frac{(1)-(2)}{0.294}$} & \multicolumn{3}{|c|}{$(1)-(3)$} & \multicolumn{2}{|c|}{$(1)-(4)$} \\
\hline & & & & & & & & & & & & & & & 0.344 & $* *$ & 0.418 & $* * *$ \\
\hline Capital Structure & 428 & 3.837 & 6.051 & 74 & 1.814 & 2.222 & 159 & 2.682 & 4.265 & 132 & 2.411 & 4.070 & 2.023 & $* * *$ & 1.155 & $* *$ & 1.425 & $* *$ \\
\hline Investment & 391 & 0.125 & 0.079 & 68 & 0.126 & 0.077 & 150 & 0.143 & 0.102 & 118 & 0.159 & 0.110 & -0.001 & & -0.019 & $* *$ & -0.035 & $* * *$ \\
\hline Ln Employee & 420 & 3.064 & 1.421 & 70 & 3.259 & 1.477 & 152 & 3.243 & 1.471 & 128 & 2.901 & 1.592 & -0.194 & & -0.179 & & 0.163 & \\
\hline ROA & 351 & 0.054 & 0.080 & 49 & 0.071 & 0.068 & 92 & 0.041 & 0.102 & 93 & 0.047 & 0.099 & -0.017 & & 0.012 & & 0.007 & \\
\hline OROA & 425 & 0.110 & 0.080 & 74 & 0.116 & 0.072 & 158 & 0.113 & 0.078 & 131 & 0.111 & 0.078 & -0.006 & & -0.003 & & -0.001 & \\
\hline Tobin's Q & 419 & 1.632 & 1.000 & 73 & 1.598 & 0.693 & 151 & 1.748 & 1.194 & 128 & 1.743 & 1.267 & 0.034 & & -0.116 & & -0.111 & \\
\hline $\begin{array}{l}\text { Working capital } \\
\text { growth }\end{array}$ & 371 & -0.291 & 2.530 & 65 & 0.174 & 1.685 & 146 & -0.101 & 1.627 & 113 & -0.118 & 1.707 & -0.465 & & -0.190 & & -0.173 & \\
\hline Short debt change & 426 & -0.070 & 1.993 & 74 & 0.000 & 0.951 & 158 & 0.109 & 1.172 & 132 & 0.124 & 1.018 & -0.070 & & -0.179 & & -0.194 & \\
\hline Advertising & 427 & 0.008 & 0.019 & 74 & 0.014 & 0.030 & 159 & 0.016 & 0.033 & 132 & 0.017 & 0.034 & -0.006 & $* *$ & -0.008 & $* * *$ & -0.009 & $* * *$ \\
\hline Research & 427 & 0.028 & 0.056 & 74 & 0.018 & 0.038 & 159 & 0.024 & 0.052 & 132 & 0.024 & 0.051 & 0.010 & & 0.004 & & 0.004 & \\
\hline Firm age & 428 & 53.439 & 46.681 & 74 & 61.311 & 35.766 & 159 & 51.264 & 48.129 & 132 & 46.727 & 38.115 & -7.872 & & 2.175 & & 6.712 & \\
\hline Return volatility & 418 & 0.098 & 0.065 & 73 & 0.091 & 0.030 & 150 & 0.102 & 0.039 & 127 & 0.104 & 0.035 & 0.007 & & -0.004 & & -0.006 & \\
\hline Ln cash & 418 & 6.498 & 1.601 & 73 & 6.196 & 1.487 & 156 & 6.364 & 1.644 & 128 & 6.364 & 1.494 & 0.303 & & 0.134 & & 0.134 & \\
\hline Sales/asset & 428 & 0.862 & 0.702 & 74 & 1.027 & 0.665 & 159 & 0.900 & 0.557 & 132 & 0.912 & 0.637 & -0.165 & * & -0.038 & & -0.050 & \\
\hline Expense/asset & 346 & 0.170 & 0.154 & 66 & 0.210 & 0.186 & 145 & 0.188 & 0.173 & 116 & 0.208 & 0.183 & -0.041 & $*$ & -0.018 & & -0.039 & $* *$ \\
\hline Cost/asset & 428 & 0.570 & 0.600 & 74 & 0.670 & 0.574 & 159 & 0.560 & 0.478 & 132 & 0.567 & 0.522 & -0.100 & & 0.010 & & 0.002 & \\
\hline Depreciation/asset & 414 & 0.035 & 0.022 & 72 & 0.039 & 0.023 & 156 & 0.036 & 0.021 & 125 & 0.037 & 0.024 & -0.004 & & -0.001 & & -0.002 & \\
\hline
\end{tabular}

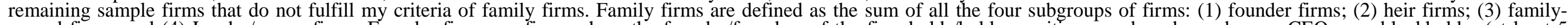

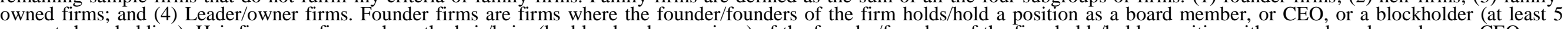

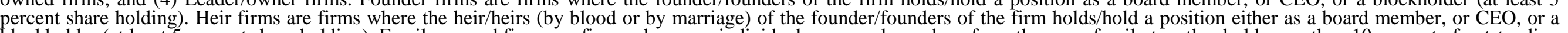

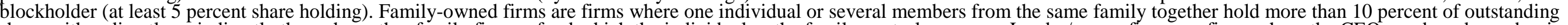

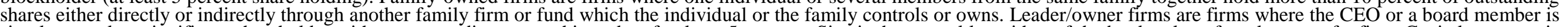

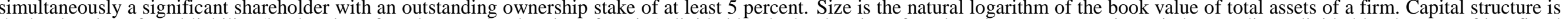

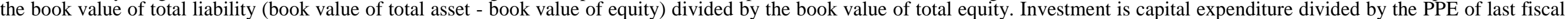

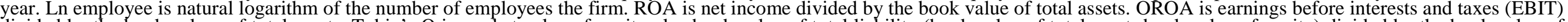

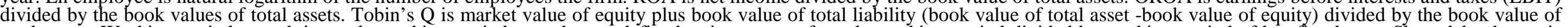

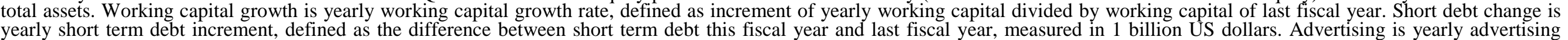

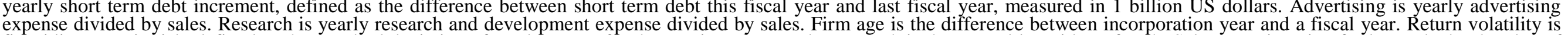

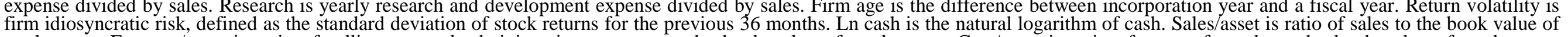

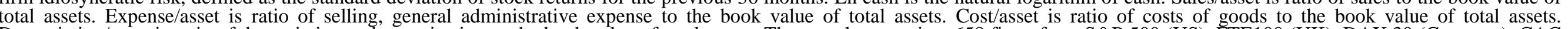

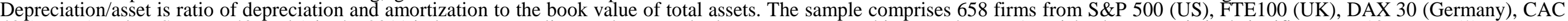

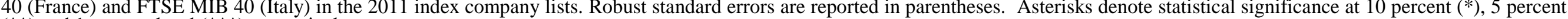
$(* *)$ and 1 percent level $(* * *)$ respectively. 
Appendix 4 Fixed effect estimation of founder firms outperformance in OROA during the crisis (non-financial firms)

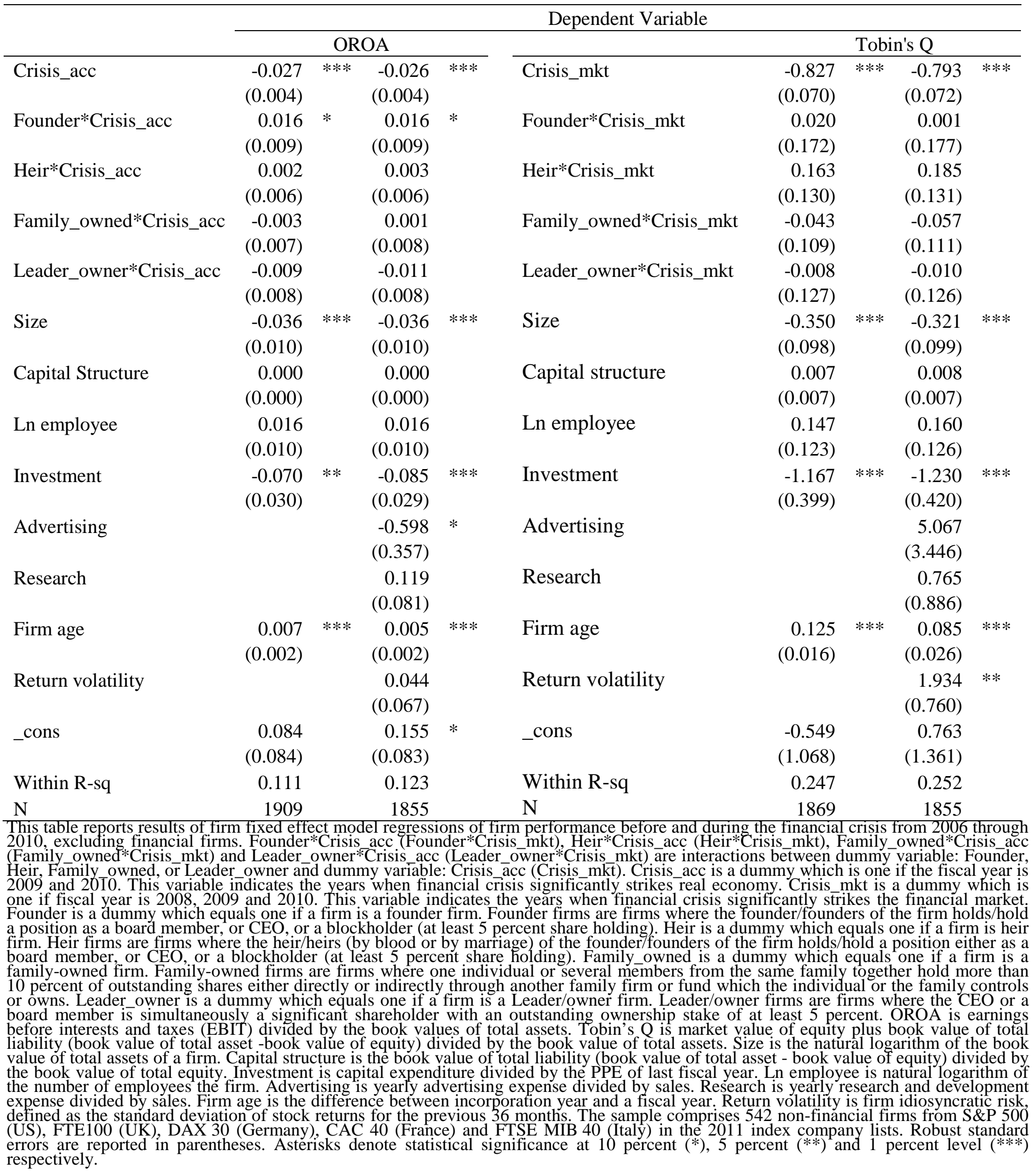

